This PDF is a selection from a published volume from the National Bureau of Economic Research

Volume Title: Perspectives on the Economics of Aging

Volume Author/Editor: David A. Wise, editor

Volume Publisher: University of Chicago Press

Volume ISBN: 0-226-90305-2

Volume URL: http://www.nber.org/books/wise04-1

Conference Date: May 17-20, 2001

Publication Date: June 2004

Title: Wealth Portfolios in the United Kingdom and the United States

Author: James Banks, Richard Blundell, James Smith

URL: http://www.nber.org/chapters/c10344 


\title{
Wealth Portfolios in the United Kingdom and the United States
}

\author{
James Banks, Richard Blundell, and James P. Smith
}

\section{Introduction}

In this paper, we document and attempt to explain differences between the U.S. and U.K. household wealth distributions, with an emphasis on the quite different portfolios held in stock and housing equities in the two countries. As a proportion of their total wealth, British households hold relatively small amounts of financial assets - including equities in stockcompared to American households. In contrast, British households appear to move into home ownership at relatively young ages, and a large fraction of their household wealth is concentrated in housing. Finally, the age gradient in home equity appears to be much steeper in the United Kingdom whereas U.S. households exhibit a steeper age gradient in stock equity.

Moreover, these portfolio differences between the two countries are not

James Banks is reader in economics at University College London and deputy research director of the Institute for Fiscal Studies where he also directs the Centre for Economic Research on Ageing. Richard Blundell is Leverhulme Research Professor of Economics at University College London, and director of the ESRC Centre for the Microeconomic Analysis of Fiscal Policy and director of research at the Institute for Fiscal Studies. James P. Smith is a senior economist at RAND.

Banks acknowledges the financial support of the Leverhulme Trust through the research program The Changing Distribution of Consumption, Economic Resources and the Welfare of Households. Blundell would like to thank the ESRC Centre for the Microeconomic Analysis of Fiscal Policy. Smith's research was supported by a grant from the National Institute on Aging. This paper benefited from the expert programming assistance of David Rumpel and Patty St. Clair. Many thanks are due to François Ortalo-Magne and John Shoven for useful discussions and comments. We are also grateful to participants at the National Bureau of Economic Research (NBER) Economics of Aging conference (June 2001) and the British Household Panel Survey (BHPS) Annual Conference (July 2001) for comments. The usual disclaimer applies. 
temporally static, as important changes have been taking place in both countries in their housing and equity markets. Especially in Britain, there have been some fundamental changes in national policies that have been aimed at encouraging wider rates of home ownership and greater participation in the equity market.

As well as large volatility in real rates of return in housing and corporate equity markets, the last few decades have also witnessed periods of unusually large capital gains in both the housing and stock market. Besides the large background risk in their incomes, young householders in Britain and the United States face considerable housing price and stock price risks when deciding on their desired portfolio balances. While price risk in the equity market appears to be historically similar in the two countries, housing price risk may be much higher in the United Kingdom in recent decades.

In addition, institutional differences between the countries imply much younger new home buyers in the United Kingdom than in the United States. In this paper, we argue that the higher housing price volatility in the United Kingdom combined with much younger entry into home ownership is an important factor accounting for the relatively small participation of young British householders in the stock market. We show it is important to acknowledge the dual role of housing — providing both wealth and consumption services - in understanding wealth accumulation differences between the United States and the United Kingdom. Institutional differences, particularly in housing markets, that affect the demand and supply of housing services turn out to be important in generating portfolio differences between the two countries. In particular, these differences in housing price risk imply steeper life-cycle accumulations in housing and less steep accumulations in stock equity over the life cycle in the United Kingdom.

This paper is divided into six sections. The first describes the data sources used, whereas section 5.2 presents some basic facts about the distribution of total wealth as well as the housing and financial asset components that make up that total. The third section highlights some salient differences between British and American housing and equity markets. The next section summarizes some theoretical reasons why young British people may desire not to hold much of their household wealth in the form of corporate equity. Section 5.5 tests some implications of this theoretical perspective using comparative international data on the characteristics of young homeowners. The final section summarizes our conclusions.

\subsection{Data Sources}

To make wealth comparisons, for the United States we primarily use the Panel Study of Income Dynamics (PSID), which has gathered almost thirty years of extensive economic and demographic data on a nationally 
representative sample of approximately 5,000 (original) families and 35,000 individuals who live in those families. Unlike many other prominent American wealth surveys, the PSID is representative of the complete age distribution. Wealth modules were included in the 1984, 1989, 1994, and 1999 waves of the PSID and all four waves are examined here. In addition, questions on housing ownership, value, and mortgage were asked in each calendar year wave of the PSID.

For the United Kingdom, we use the British Household Panel Survey (BHPS). The BHPS has been running annually since 1991 and, like the PSID, is also representative of the complete age distribution. The wave 1 sample consisted of some 5,500 households and 10,300 individuals, and continuing representativeness of the survey is maintained by following panel members wherever they move in the United Kingdom and also by including in the panel the new members of households formed by original panel members.

The BHPS contains annual information on individual and household income and employment as well as a complete set of demographic variables. Data are collected annually on primary housing wealth and occasionally on secondary housing wealth and vehicle wealth. In 1995 the BHPS included an individual wealth module which forms the basis of the wealth information used here. Since some components of wealth are collected at the household level, we construct a household wealth definition from wave 5 to use in what follows. Hence we draw a subsample of BHPS households for whom the head and the spouse (where relevant) remain present and who successfully complete the 1995 wealth module. This results in a total of 4,688 households observed in the panel for between one and eight waves.

Appendix table 5A.1 contains a side-by-side account of the elements that comprise household wealth in the two surveys. Besides housing equity, PSID nonhousing assets are divided into seven categories: other real estate (which includes any second home); vehicles; farm or business ownership; stocks, mutual funds, investment trusts, and stocks held in individual retirement accounts (IRAs); checking and savings accounts, certificates of deposit (CDs), treasury bills, savings bonds, and liquid assets in IRAs; bonds, trusts, life insurance, and other assets; and other debts. The PSID wealth modules include transaction questions about purchases and sales so that active and passive (capital gain) saving can be distinguished.

While the BHPS detail on assets is similar to the PSID, there are some differences. Most important, no questions were asked about business equity in the BHPS. To make wealth concepts as comparable as possible, business equity was excluded from total wealth in the PSID. ${ }^{1}$ Neither survey

1. To the extent that omitted components vary across countries, and particularly for groups converting business wealth to personal wealth, these may be important issues that deserve further investigation. Given that the majority of our analysis will be most pertinent to young households, however, pension wealth will be important only in the context of long-term 
oversamples high income or wealth households, which — given the extreme skew in the wealth distribution - implies that both surveys understate the concentration of wealth among the extremely wealthy. While this lack of a high wealth oversample is typically a limitation in describing wealth distributions, it has the advantage here of greater comparability between the data sets. Another limitation common to both countries is that neither provides any measure of private pension or government pension wealth.

There are also differences in the way financial asset wealth was collected. Both surveys collect wealth information in four broad classes, but the classes are somewhat different in each country. The PSID uses checking accounts, stocks, other saving (predominantly bonds), and debts, whereas the BHPS uses bank accounts, savings accounts, investments, and debts. For each of the BHPS classes, there are also a series of dummy variables recording whether each individual has funds in a particular component of each category. In addition, for investments a variable records which of the various subcomponents is the largest.

The following procedure makes the wealth categories as comparable as possible when disaggregated data are necessary. Bank and savings accounts are aggregated in the BHPS. The investments category is subdivided as follows: For individuals who report no ownership of either national savings bonds, national savings certificates, or premium bonds, we code their entire investment wealth as shares (27 percent who report owning investment wealth). For those who report no share ownership, mutual funds, personal equity plans or "other" investments, we code the investment wealth as bonds (44 percent of those with investment wealth). For those reporting both "types" of investment wealth (28 percent, we allocate wealth entirely to either shares or bonds, according to asset type of the largest asset.

Finally, an issue of comparability arises over the unit of assessment to which the wealth module applies. More specifically, it is not possible to get a single estimate of household wealth in any subcategory of financial wealth from the BHPS. This is because every individual was asked to complete the wealth questionnaire and having reported a total amount for, say, investments was simply asked "Are any of your investments jointly held with someone else?" This framework creates obvious problems in generating a measure of household wealth. We address this issue by using a bounding approach. For each of the financial wealth categories in the BHPS, two measures are reported. First, we compute an upper bound under the assumption that any jointly held asset classes are actually held solely by the individual (the limit of the case where the individual owns "most" of the asset). Second, we compute a lower bound under the assumption that an individual only owns $1 / N$ th of the asset class in which joint ownership is re-

saving. As such, it will be relatively small in present discounted value terms, relatively safe, and important for us, inaccessible for short- or medium-run smoothing purposes. Hence in what follows we do not control for what pension differences there are across countries. 
ported, where $N$ is the number of adults in the household. To compute the upper bound of net financial wealth, we add the upper bounds for the asset components and subtract the lower bound of the debt component and vice versa for the lower bound. In this paper, both lower- and upper-bound estimates are presented. Fortunately, our conclusions appear not be sensitive to how this problem is resolved, and the availability of individual-level wealth holdings will be an advantage for certain later aspects of our analysis.

\subsection{Comparing the Wealth Distribution in the United States and Britain}

We describe here the main characteristics of wealth distributions in the United Kingdom and United States, highlighting similarities and differences. We use two concepts of household wealth - total household wealth (excluding business equity) and total financial assets. Since the BHPS wealth module was only fielded in 1995, we confine our cross-section comparisons to the 1994 wave of the PSID. To deal with currency differences, the U.K. data (collected in September 1995) are converted into U.S. dollars using the then exchange rate of 1.5525 , and all financial statistics for both countries are presented in 1995 U.S. dollars. ${ }^{2}$

Table 5.1 lists mean values of wealth and its components for both countries. Total household wealth is about one-third higher in the United States, but within-asset category differences are far larger. Total nonfinancial assets held by households are reasonably similar in the United Kingdom and United States. Within that subaggregate, British households actually have greater absolute and relative amounts of wealth in home equity than American households do. Converted to a common currency, mean housing equity is almost $\$ 10,000$ more than their American counterparts. Similarly, British households hold 62 percent of their total household wealth as home equity: The comparable percent for American households is only 34 percent.

The other striking difference between the United Kingdom and United States lies instead in financial wealth where mean values in America are more than twice those in Britain. These differences exist in all components of financial wealth, but they are particularly large in stock market equity. On average, in the mid-1990s American households owned about \$20,000 more in corporate equity than their British counterparts.

Given the extreme skew in wealth distributions, means can be poor summary statistics for wealth. In a previous paper (Banks, Blundell, and Smith 2000), we have shown that total net wealth and financial wealth distributions in both countries were extremely unequally distributed. Turning to

2. Given that this is close to the Organization for Economic Cooperation and Development (OECD) purchasing power parity (PPP) conversion rates for this time (1.55 in 1994 and 1.53 in 1995) our comparisons are unaffected by the use of exchange rate as opposed to PPP conversion factors. 
Table 5.1

Household Wealth and Components in the United States and the United Kingdom (1995 USS, thousands)

\begin{tabular}{lcrr}
\hline & & \multicolumn{2}{c}{1995 BHPS } \\
\cline { 3 - 4 } Wealth Category & 1994 PSID & Lower & Upper \\
\hline Net Home Equity & 44.8 & 54.3 & 54.3 \\
Other Real Estate & 24.2 & 9.5 & 9.5 \\
Net Vehicle Wealth & 10.9 & 3.8 & 3.8 \\
$\quad$ Net Tangible Assets & 79.9 & 67.7 & 67.7 \\
Stocks and Mutual Funds & 28.8 & 7.7 & 10.3 \\
Liquid Assets & 19.5 & 10.0 & 12.8 \\
Other Financial Assets & 9.5 & 4.7 & 5.2 \\
Other Debts & 6.1 & 1.6 & 2.0 \\
$\quad$ Net Financial Assets & 51.7 & 19.4 & 26.7 \\
Total Wealth & 131.6 & 87.2 & 94.4 \\
\hline
\end{tabular}

differences between countries, large differences did not emerge for the typical household. Median total net worth was slightly higher among British households, whereas median financial assets were somewhat greater among American households. Rather, the critical differences lie in the upper tails of the wealth distribution, especially in financial assets. No matter which assumption about joint or separate ownership of assets is made in the BHPS, the top fifth of American households have considerably more financial wealth than the top fifth of British households. The between country discrepancy in financial wealth expands rapidly as we move up the respective financial wealth distributions.

These wealth differences are not due to age and income differences between the countries. Banks, Blundell, and Smith (2000) demonstrate that, within age groups, net financial wealth in both countries increases with household income albeit in a highly nonlinear way and that at almost all points in the age-income distribution, U.S. households are holding more financial wealth than their U.K. counterparts. The same breakdown for net total wealth shows that for almost all of the younger age-income groups, U.K. households have at least as much wealth, if not slightly more, than their U.S. counterparts.

\subsection{A Comparison of Four Markets-Housing and Stock Markets in the United States and the United Kingdom}

To set a background for this paper, we first describe the most salient trends in housing and equity markets in these two countries during the last few decades. Our description includes trends and differences in rates of ownership, rates of return, and amounts of wealth held in these forms. 
Proportion of Households Who are Homeowners in Year $t$, by Age of the Head

\begin{tabular}{lcccccccc}
\hline Age Range & 1969 & 1974 & 1979 & 1984 & 1989 & 1994 & 1997 & 1999 \\
\hline United Kingdom & & & & & & & & \\
$\quad 20-29$ & 0.418 & 0.456 & 0.508 & 0.537 & 0.518 & 0.489 & & 0.424 \\
$30-39$ & 0.529 & 0.596 & 0.648 & 0.692 & 0.729 & 0.688 & & 0.669 \\
$40-49$ & 0.476 & 0.568 & 0.615 & 0.718 & 0.772 & 0.787 & & 0.755 \\
$50-59$ & 0.476 & 0.489 & 0.517 & 0.631 & 0.711 & 0.770 & & 0.779 \\
$60-69$ & 0.446 & 0.443 & 0.490 & 0.527 & 0.624 & 0.702 & & 0.722 \\
$70+$ & 0.411 & 0.419 & 0.425 & 0.486 & 0.553 & 0.585 & & 0.615 \\
Total & 0.465 & 0.498 & 0.537 & 0.603 & 0.655 & 0.676 & & 0.673 \\
United States & & & & & & & & \\
$20-29$ & 0.326 & 0.310 & 0.288 & 0.246 & 0.233 & 0.272 & 0.277 & \\
$30-39$ & 0.604 & 0.661 & 0.665 & 0.590 & 0.530 & 0.528 & 0.530 & \\
$40-49$ & 0.737 & 0.751 & 0.760 & 0.738 & 0.766 & 0.704 & 0.695 & \\
$50-59$ & 0.700 & 0.770 & 0.778 & 0.806 & 0.799 & 0.811 & 0.810 & \\
$60-69$ & 0.785 & 0.736 & 0.756 & 0.776 & 0.796 & 0.830 & 0.870 & \\
$70+$ & 0.639 & 0.751 & 0.760 & 0.681 & 0.699 & 0.717 & 0.770 & \\
Total & 0.639 & 0.631 & 0.624 & 0.601 & 0.609 & 0.626 & 0.651 & \\
\hline
\end{tabular}

\subsubsection{Rates of Asset Ownership: Housing}

Table 5.2 lists the proportion of households who are homeowners, by the age of head of household, for selected years in both countries. While aggregate rates of home ownership are now not that dissimilar (around twothirds in both countries in the most recent year listed), there are striking differences by age. ${ }^{3}$ Home ownership rates amongst young households are far higher in the United Kingdom than in the United States, with differences as big as 20 percentage points for householders between the ages of twenty and twenty-nine. While not as large, the fraction of households aged thirty-thirty-nine is currently double digit larger in the United Kingdom. The offset to the greater rates of home ownership among young British householders is the much lower historical rates among older households in the United Kingdom. For example, among those over age sixty, the prevalence of owning a home in 1984 was more than 20 percentage points larger in the United States than in the United Kingdom.

Table 5.2 also suggests that there are stronger cyclic and trend effects on home ownership rates in the United Kingdom compared to the United States. Although the levels are always above their U.S. counterparts, there was a sharp upswing in home ownership among the youngest British household heads (those between the ages of twenty and twenty-nine),

3. Figures for the United Kingdom are computed from the FES microdata to enable the comparison with 1985. However, calculations confirm that home ownership rates in the 1995 BHPS data match those in the 1995 FES to well within 1 percentage point for all age groups and for the population as a whole. 
which reached its peak between 1984 and 1988, during the height of a housing boom. Since that year, the trend reversed, and the proportion of homeowners amongst the youngest group in the United Kingdom fell. With lower amplitude, a similar pattern exists among those aged thirty-thirtynine. We return below to the question of why cyclic variation in home ownership may be larger in the United Kingdom.

There are impressive cohort effects in U.K. home ownership with secular changes concentrated among older households. For example, among British households aged fifty-fifty-nine, home ownership rates increased by almost 30 percentage points after 1974 . While not confined to that time period, the size of the increase in home ownership is largest in the five-year interval between 1979 and 1984.

Table 5.3 presents the same data separately for U.K. households based on whether the head had some postcompulsory education. This dramatic secular increase in home ownership in Britain is concentrated among those with less education. Once again examining those aged fifty-fifty-nine, there was a 32 percentage point increase in home ownership among those with no post-compulsory schooling compared to a 12 percentage point increase among those households whose head had moved beyond compulsory schooling levels.

The structure of these differences in home ownership between the United Kingdom and United States raise several questions. One question is what accounted for the magnitude and structure of the dramatic secular shift in the United Kingdom. Given its timing, one contributing factor is the "right-to-buy" scheme for public housing tenants that was introduced

Table 5.3

U.K. Home Ownership Rates by Age, Year, and Schooling Level of Head

\begin{tabular}{|c|c|c|c|c|c|}
\hline Age Range & 1979 & 1984 & 1989 & 1994 & 1999 \\
\hline \multicolumn{6}{|c|}{ No Post Compulsory Education } \\
\hline $20-29$ & 0.384 & 0.450 & 0.468 & 0.421 & 0.341 \\
\hline $30-39$ & 0.526 & 0.567 & 0.590 & 0.598 & 0.596 \\
\hline $40-49$ & 0.515 & 0.645 & 0.681 & 0.680 & 0.679 \\
\hline $50-59$ & 0.413 & 0.540 & 0.648 & 0.699 & 0.739 \\
\hline $60-69$ & 0.410 & 0.447 & 0.549 & 0.634 & 0.680 \\
\hline $70+$ & 0.376 & 0.425 & 0.454 & 0.471 & 0.583 \\
\hline Total & 0.436 & 0.508 & 0.559 & 0.579 & 0.622 \\
\hline \multicolumn{6}{|c|}{ With Post Compulsory Education } \\
\hline $20-29$ & 0.617 & 0.677 & 0.623 & 0.594 & 0.525 \\
\hline $30-39$ & 0.814 & 0.803 & 0.844 & 0.795 & 0.767 \\
\hline $40-49$ & 0.792 & 0.842 & 0.874 & 0.861 & 0.868 \\
\hline $50-59$ & 0.766 & 0.802 & 0.826 & 0.865 & 0.887 \\
\hline $60-69$ & 0.729 & 0.736 & 0.788 & 0.828 & 0.916 \\
\hline $70+$ & 0.660 & 0.689 & 0.793 & 0.802 & 0.816 \\
\hline Total & 0.735 & 0.771 & 0.807 & 0.803 & 0.785 \\
\hline
\end{tabular}


in 1980. Under this scheme those households who had been renting in government owned housing for a certain minimum duration were given an automatic right to buy their home from the local authorities. The house was valued at current market value but discounts, varying between 30 percent and 60 percent, were applied according to how long they had been living there.

The right-to-buy program is consistent with the main features of the data in tables 5.2 and 5.3. Most important, public housing tenants are concentrated among the less educated where most of the increase in home ownership occurred. Secondly, the concentration of change was among middle-age and older households who had longer tenure and could meet the minimum tenure requirement and who also may have accumulated a bit of savings for a down payment.

The more difficult question arising from table 5.2, and one on which we focus in this paper, is why rates of home ownership are much higher among younger U.K. households. One possibility is the structure of mortgages themselves. The typical U.K. model is characterized by a low down payment ( 5 percent to 10 percent), variable interest rates, and a fairly low takeup of mortgage interest insurance. The typical U.S. mortgage has a higher down payment ( 20 percent), fixed interest rates, ${ }^{4}$ and often is accompanied by mortgage interest insurance, generating a more stable intertemporal financial commitment (see Chiuri and Jappelli 2000) for an institutional differences discussion). Differences in down payment requirements alone shorten the time (compared to American households) it takes young British households to save in order to reach their required down payments. ${ }^{5}$

Differences in housing wealth accumulation could be driven by other factors in the housing market. Rental market rigidities or failures commonly thought to exist in the United Kingdom could be one issue. Renters' right rules are far more common in the United Kingdom, making it difficult to evict existing tenants. This may explain differences in ownership rates among the young but not differences in the amount and growth of net equity in housing held by homeowners. The low ownership rates among older British most likely lie in a combination of the widespread availability

4. In the 1996 PSID sample, only 20.8 percent of households with mortgages had variable rate mortgages.

5. The role of cross-country differences in tax treatment is interesting since the U.S. tax treatment is actually more favorable than in the United Kingdom. While mortgage interest payments had been tax deductible in the United Kingdom, over the past twenty years this has been gradually phased out and all tax relief has been abolished from April 2000. U.S. households still receive full tax deductibility on all mortgage interest payments. Capital gains on primary residences are untaxed in both countries. These tax differences may affect ownership rates and equity payments differently. Importantly, there is no tax advantage to carrying mortgage debt in the United Kingdom, whereas this advantage is substantial in the United States. 
Table 5.4

PSID Housing Equity and Its Components: Homeowners Only

(1984-1996; in thousands of 1995 US\$)

\begin{tabular}{|c|c|c|c|c|c|}
\hline \multirow[b]{2}{*}{ Year } & \multicolumn{2}{|c|}{ House Value } & \multicolumn{2}{|c|}{$\begin{array}{c}\text { Mortgage } \\
\text { Outstanding }\end{array}$} & \multirow[b]{2}{*}{ Net Equity Mean } \\
\hline & Mean & Median & Mean & Median & \\
\hline 1984 & 94.1 & 78.1 & 25.8 & 11.4 & 68.3 \\
\hline 1985 & 97.6 & 82.3 & 27.6 & 11.0 & 70.0 \\
\hline 1986 & 101.8 & 80.4 & 28.4 & 11.4 & 73.4 \\
\hline 1987 & 108.4 & 84.0 & 31.1 & 12.9 & 77.3 \\
\hline 1988 & 112.6 & 80.9 & 33.2 & 13.4 & 79.4 \\
\hline 1989 & 115.6 & 83.4 & 35.3 & 14.3 & 80.3 \\
\hline 1990 & 115.3 & 79.8 & 35.2 & 15.4 & 80.1 \\
\hline 1991 & 110.6 & 79.3 & 34.8 & 14.3 & 75.8 \\
\hline 1992 & 109.5 & 80.4 & 35.0 & 12.9 & 74.5 \\
\hline 1993 & 112.0 & 83.5 & 38.4 & 15.6 & 73.6 \\
\hline 1994 & 114.7 & 86.9 & 42.0 & 14.8 & 72.7 \\
\hline 1995 & 114.5 & 90.0 & 39.7 & 15.0 & 74.8 \\
\hline 1996 & 116.0 & 88.2 & 39.9 & 15.7 & 76.1 \\
\hline
\end{tabular}

of public housing to their generations as well as their much lower levels of economic status compared to U.S. households.

Tables 5.4 and 5.5 provide another view of the housing market dynamics in the two countries by listing yearly values of home values and outstanding mortgages for homeowners. ${ }^{6}$ The value of British homes is always above that of their American counterparts. For example, in 1994 the median value of a home in the United Kingdom is about 14 percent higher than the median value of a home in the United States. Unless one has a strong prior that British homes are in some sense "better" than American homes, this price differential may simply indicate that the price of housing is higher in the United Kingdom. If so, the advantage of British households in housing wealth raises some conceptual questions of whether this type of wealth advantage should be treated on a par with wealth differences that emerge in other assets. If British homes are more expensive for the same quality, and demand is inelastic, British households will spend more on housing as discussed in section 5.4.

Tables 5.4 and 5.5 also indicate that the higher net equity held in British homes in part reflects higher housing prices in the United Kingdom but also the smaller outstanding mortgages in the United Kingdom. This mortgage differential prevails in spite of the fact that initial down payment requirements are lower in the United Kingdom than in the United States.

6. Over the years in common the time series of home values among homeowners in table 5.3 captures the swings in home prices contained in figure 5.3. No questions were asked in the BHPS about housing in 1992, and no mortgage questions were asked in 1991. 
BHPS Housing Equity and Its Components: Homeowners Only (1991-1998; in thousands of 1995 US\$)

\begin{tabular}{ccccccc}
\hline & \multicolumn{2}{c}{} & \multicolumn{3}{c}{$\begin{array}{c}\text { Mortgage } \\
\text { Outstanding }\end{array}$} \\
\cline { 2 - 3 } Year & Mean & Median & & Mean & Median & Net Equity Mean \\
\cline { 2 - 3 } 1991 & 137.8 & 112.9 & & n.a. & n.a. & n.a. \\
1993 & 122.3 & 98.9 & & 34.4 & 13.2 & 88.0 \\
1994 & 120.0 & 96.7 & & 34.4 & 14.5 & 85.6 \\
1995 & 115.2 & 93.2 & & 34.9 & 18.6 & 80.2 \\
1996 & 117.6 & 95.8 & & 32.9 & 16.7 & 84.7 \\
1997 & 119.4 & 95.4 & & 37.8 & 20.5 & 81.6 \\
1998 & 124.5 & 99.6 & & 35.5 & 19.9 & 89.0 \\
\hline
\end{tabular}

Note: n.a. $=$ not available.

This in turn suggests that compared to their U.S. counterparts, British households may not engage in significant amounts of refinancing their homes as real housing prices rise and capital gains are accumulated. Consistent with this view, note the significant increase in outstanding mortgages in the United States at a pace that parallels that of real housing prices so that net housing equity has remained flat. While the refinancing of homes has become reasonably commonplace in the United States over the last decade or so (data from the 1996 PSID indicate that 37 percent of households with existing mortgages had refinanced), this phenomenon appears to be much less important in the United Kingdom. British households seem to be far more cautious in using wealth accumulated through capital gains in housing for other purposes.

\subsubsection{Rates of Asset Ownership: Stock}

Using the PSID, one-quarter of U.S. households directly owned some stock in 1984, a fraction that grows to 40 percent by 1999. Direct share ownership was far less common among British households, especially in the early 1980s. Figure 5.1 plots the time-series pattern of equity ownershipin the United Kingdom between 1978 and 1996. By the mid-1980s, British household equity ownership rates had been stable and hovered just below 10 percent-well less than the U.S. figure in 1984. Starting in 1984, equity ownership grew more rapidly in the United Kingdom than in the United States. While the gap in equity ownership has narrowed, by the mid-1990s almost one-quarter of British households directly owned stock compared to one-third of American households.

Table 5.6 lists stock ownership rates by age in a form similar to that displayed in tables 5.4 and 5.5. Consistent with figure 5.1, secular changes in British stock ownership look much like classic calendar year effects. There 


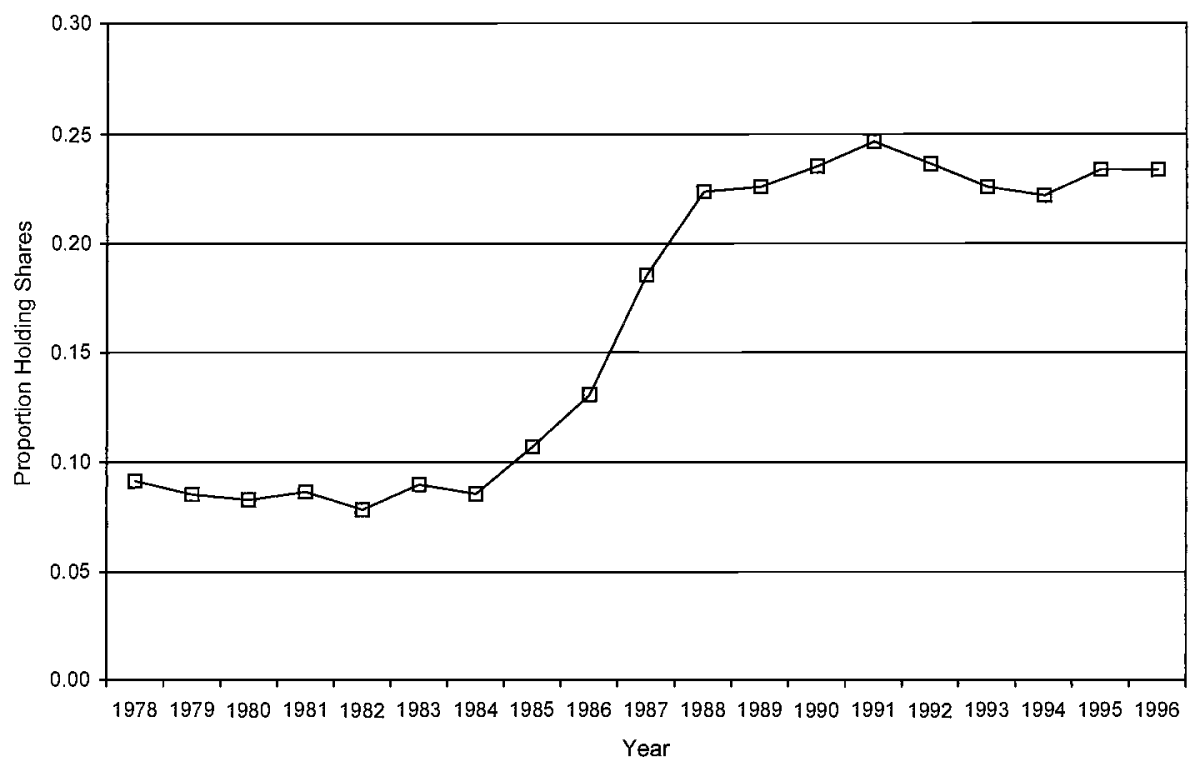

Fig. 5.1 Time series of household share-ownership rates from FES data

was almost no change between 1979 and 1984, followed by a sharp increase during the next five years with very little change thereafter. These increases in stock ownership were slightly larger among middle-age households, but in general one is struck by the near uniformity in increases in prevalence across all age groups. Not shown in table 5.6, stock ownership expanded by a somewhat greater amount among more educated British households. ${ }^{7}$

The same questions asked about home ownership are relevant to equity markets as well. Why the intercountry differences, and why the massive secular shifts in the United Kingdom? In the United Kingdom most of this increase was concentrated in a four-year period from 1985 to 1989, coinciding with the flotation of previously nationalized public utilities such as British Telecom (1984) and British Gas (1986). Around this time, the U.K. government introduced also a further set of measures aimed at promoting a "share-owning democracy" - namely tax-favored employee share ownership schemes. In the United States the increase in share ownership was more gradual throughout the 1980s, no doubt induced by rising rates of return. One result of these trends was that although the stock market boom was relatively similar across the countries, the fraction of American households benefiting was far higher than in Britain throughout the 1980s and 1990s.

7. For example, between 1984 and 1989, stock ownership rates increased by 11 percentage points among those who stopped at the compulsory schooling level while it increased by 17 percentage points among household heads with more than a compulsory school education. 
Table 5.6

Proportion of Households Who are Stock Owners, by Year and Age of the Head

\begin{tabular}{llllll}
\hline Age & 1979 & 1984 & 1989 & 1994 & 1999 \\
\hline United Kingdom & & & & & \\
20-29 & 0.032 & 0.032 & 0.102 & 0.119 & 0.113 \\
30-39 & 0.054 & 0.051 & 0.187 & 0.174 & 0.211 \\
$40-49$ & 0.087 & 0.076 & 0.262 & 0.237 & 0.258 \\
$50-59$ & 0.103 & 0.127 & 0.312 & 0.276 & 0.333 \\
$60-69$ & 0.126 & 0.110 & 0.288 & 0.293 & 0.351 \\
$70+$ & 0.109 & 0.111 & 0.205 & 0.236 & 0.283 \\
Total & 0.086 & 0.086 & 0.277 & 0.222 & 0.262 \\
United States & & & & & \\
20-29 & & 0.144 & 0.160 & 0.188 & .230 \\
$30-39$ & & 0.262 & 0.258 & 0.310 & .350 \\
$40-49$ & & 0.306 & 0.358 & 0.409 & .412 \\
$50-59$ & 0.340 & 0.374 & 0.473 & .486 \\
$60-69$ & & 0.288 & 0.336 & 0.416 & .456 \\
$70+$ & & 0.208 & 0.247 & 0.271 & .399 \\
Total & & 0.248 & 0.279 & 0.341 & .398 \\
\hline
\end{tabular}

Source: U.K. data from Family Expenditure Survey (see Banks and Tanner 1999).

Note: Blank cells indicate not available.

The differences between the two countries in stock ownership are again more difficult to answer. One possible explanation is that market conditions, in particular transaction costs, taxes, or information, differ across the two countries. Certainly prior to the mid-1980s in Britain there was a tax bias away from direct holdings of equity toward wealth held in housing or occupational pensions, because equity was more heavily taxed than consumption, and housing and pensions benefited from tax advantages relative to consumption. Given the structure of the tax system these differences were significantly greater in times of high inflation. ${ }^{8}$ However, the introduction of personal equity plans and employee share ownership schemes meant that, from 1987 onward, equity could be held in a more favorably taxed manner by British households. Indeed, personal equity plans give holdings of equity an identical tax treatment to IRAs or 401(k)s, that

8. For equity, interest income tax was levied on dividend income at the investor's marginal rate (which could be as high as 83 percent during the 1970 s and 60 percent during the 1980s). In addition, investment income over a certain threshold (around $£ 2,000$ per year in mid1970 's prices) was also subject to a 15 percent investment income surcharge, although this was paid by only very few tax payers. Capital gains tax was levied on nominal capital gains until 1985 and then real gains after that date at a flat rate of 30 percent. Since 1988 real capital gains were taxed at the investor's marginal income tax rate. Since 1983 the ceiling on which mortgage interest payments were tax exempt was fixed in nominal terms, thus rapidly reducing the tax advantage to housing relative to other assets. See Banks and Blundell (1994) for details. 
is, neutral with respect to consumption. ${ }^{9}$ These tax differences are discussed in section 5.4.

Another pertinent difference is stamp duty, where a 0.5 percent charge is levied on all share transactions in the United Kingdom. But for infrequently traded portfolios, such a difference is unlikely to be behind the marked differences in share ownership observed across the two countries. Finally, there could be differences in the information individuals have about stock market investment opportunities. While this is a plausible explanation for differences in the middle of the income distribution, there are cross-country differences even in the very highest percentiles of the income or wealth distribution, where such information differences are unlikely to be so pronounced.

An alternative explanation for these differences, and possibly for higher accumulations of financial wealth in America compared to most of Europe (including the United Kingdom) more generally, involves differences in attitudes toward capitalist financial institutions (see Banks, Blundell, and Smith 2000). Especially during the 1970s and early 1980s, it is probably a fair characterization that there was more distrust of the fairness of capitalism as an economic system, at least among significant segments of the European population. The stock market is one of most vivid capitalist symbols, so this distrust may have resulted in lower average participation in equity markets among Europeans. This could be one reason why the equity boom that eventually occurred in the United Kingdom affected fewer households. However, the results obtained by Banks, Blundell, and Smith (2000) suggest that only a part of the differences in equity ownership can be explained by ideology differences between the countries.

If transaction costs, taxes, and ideology cannot fully explain the low rates of stock ownership in the United Kingdom, where do we go from there? In the following we provide a new explanation for these low rates of equity ownership that are founded not in the institutional character of the equity markets in the two countries but rather in differences in the two housing markets.

\subsubsection{Rates of Return on Assets}

Figure 5.2 plots inflation adjusted equity price indexes for both countries, each expressed relative to a 1980 base. ${ }^{10}$ The magnitude of the recent

9. On direct holdings of equity or mutual funds held outside of personal equity plans (PEPs) or IRAs, the tax treatment is also comparable across the United States and United Kingdom. Dividend income is taxed as income in both countries, and realized capital gains are taxable in both countries. However, in the United Kingdom capital gains are taxed only above a fairly sizeable annual exemption (around $\$ 10,000$ per year). In the United States capital gains are taxed at a rate lower than that in the United Kingdom (also varying with the length of the time the asset is held, but with no exemption).

10. The U.S. index is the S\&P500 while the U.K. index is the Financial Times All Share index. For an analysis of the impact of the American stock market on wealth distributions and savings behavior, see Juster et al. (2000). 


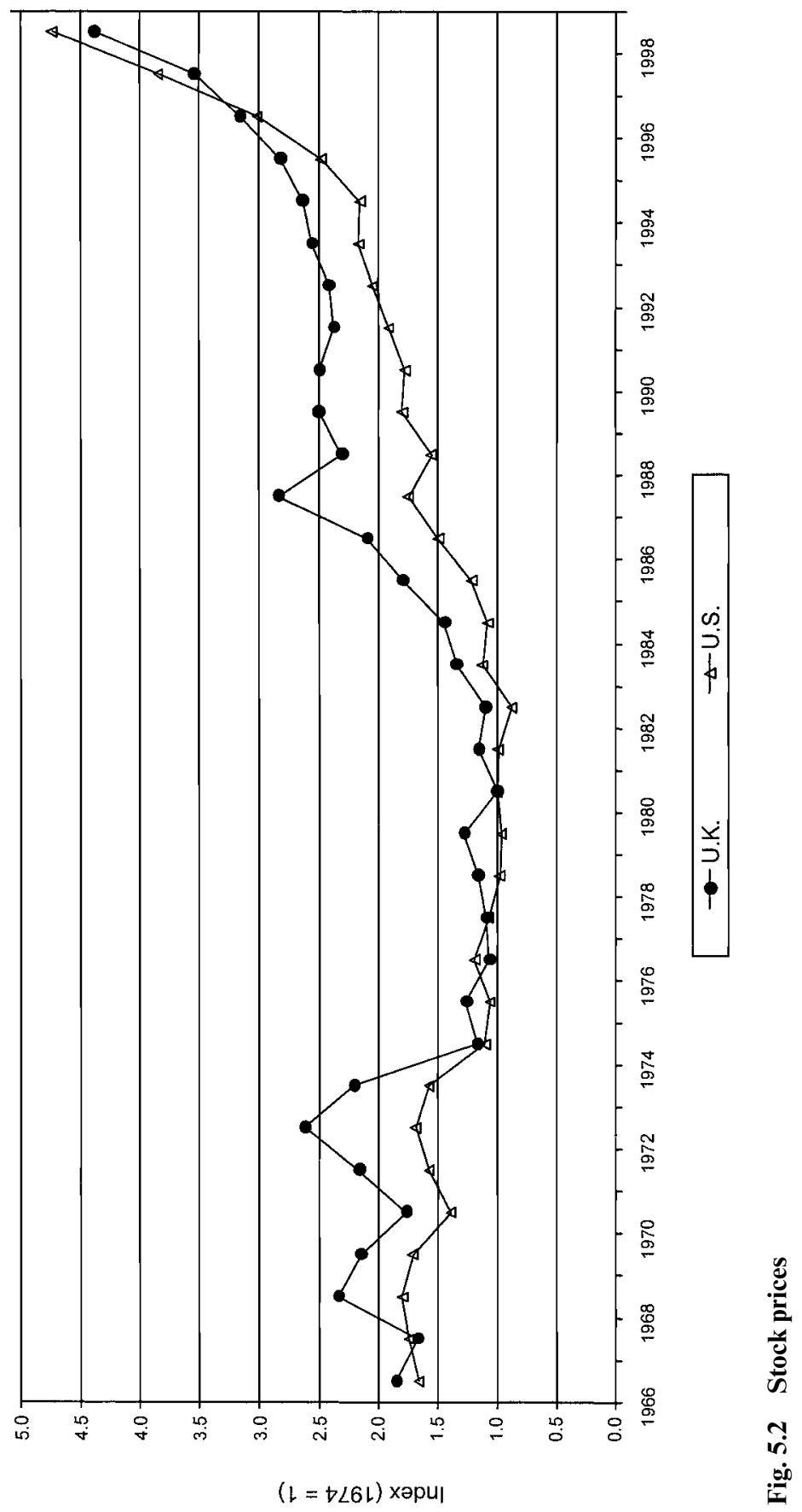


stock market boom in both countries is impressive even compared to historical equity premiums. For example, real equity prices in the United Kingdom are about two and one-half times larger in real terms in 1995 as they were in 1980 - slightly larger than the equity appreciation in the United States over the same period. Yet, measured from this 1980 base, it is remarkable how similar equity appreciation has been in both countries. The U.S. equity rates of return would be higher than those in the United Kingdom if the mid-1970s was used instead as the reference, suggesting that up to 1980 the (recent) historical experience in the stock market was more favorable in America. Still, the compelling message from figure 5.2 is that differential rates of return in each country's equity markets during the 1980s and 1990s cannot explain the quite different levels of financial wealth holdings in each country by the mid-1990s. ${ }^{11}$

Similarly, figure 5.3 shows real indices of average house prices for the United States and United Kingdom over the period 1974 to 1998. As with the indices for equity returns, both series are normalized to unity in 1980. Immediately apparent is the much larger volatility of housing prices in the United Kingdom, with real prices rising by 50 percent over the period 1980 to 1989 and then falling back to its previous value by 1992 . Over the period as a whole, however, real returns were similar across the two countries and much smaller than those realized in the equity market. In addition, the highly volatile returns to housing equity and variable interest rates leaves British households much exposed to business-cycle vagaries. This should make them much more cautious than Americans would be of refinancing their homes during housing price upswings and converting the funds into financial assets. ${ }^{12}$

The U.K. index also hides considerable differences across regions, with some being much more volatile than others. In table 5.7 we present summary statistics for house prices from the regional subindices, showing both average house prices and average house price inflation over the period as a whole, along with the corresponding variances. Immediately clear is that London and the South East of England (in which almost 30 percent of

11. For simplicity, our comparison relates to stock prices as opposed to stock returns, but dividend yields are comparable or, if anything, higher in the United Kingdom, so this cannot account for higher U.S. stock holdings (see Bond, Chennels, and Devereux 1995, for example).

12. To this point we have discussed income, housing price, and stock price risk in isolation. In deciding on the composition of their wealth portfolios, households will also consider the correlation of these risks. This is a complicated subject, and we just scratch the surface here. To examine how these risks are correlated over time, using yearly data we estimated in each country correlations between the proportional change in real gross domestic product, proportional changes in real house prices, and proportional changes in real stock prices. Proportional changes were used to attempt to isolate the risk and eliminate the deterministic component. In neither country is there any correlation between stock price risk and either housing price or gross domestic product (GDP) risk, but a significant positive correlation exists between housing price risk and GDP risk. Moreover, this correlation is significantly higher in the United Kingdom than in the United States, consistent with our view that housing supply elasticity is much smaller in the United Kingdom. 


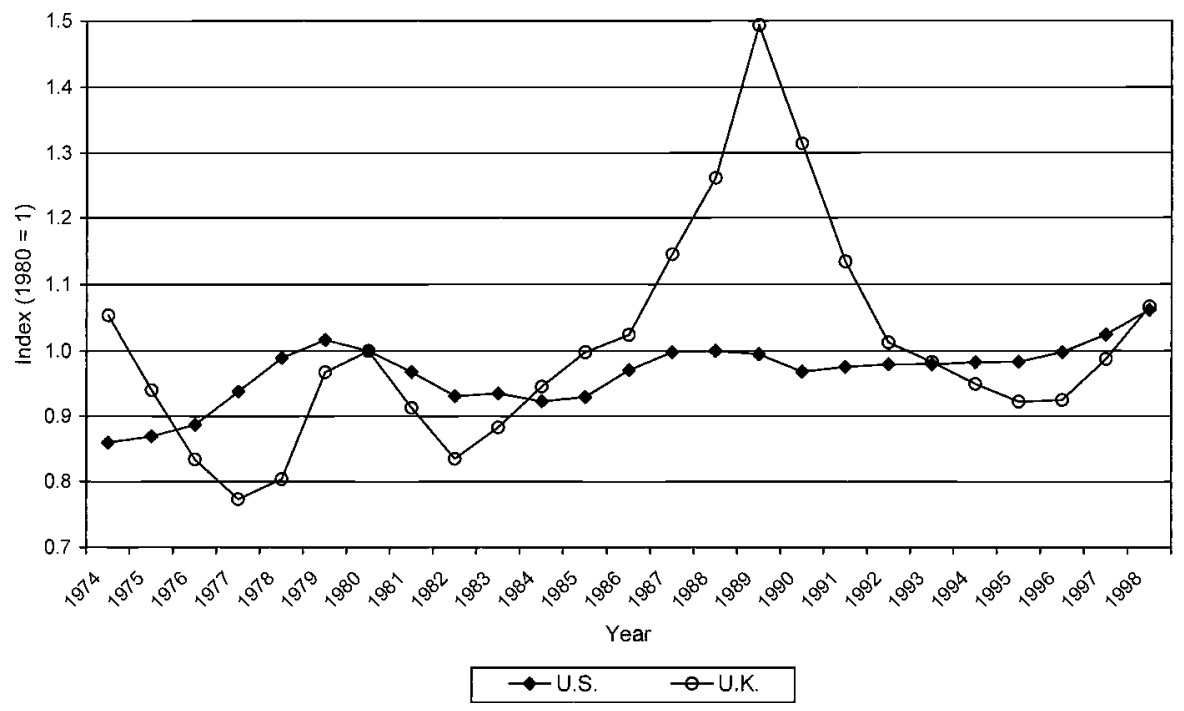

Fig. 5.3 Comparison of U.S. and U.K. housing prices

Table 5.7 Regional House Price Volatility in the United Kingdom, 1978-2000

\begin{tabular}{lccccc}
\hline Region & $\begin{array}{c}\text { Fraction of } \\
\text { Households in } \\
\text { Region (1995) }\end{array}$ & $\begin{array}{c}\text { Average Real } \\
\text { House Price } \\
(1980=1)\end{array}$ & $\begin{array}{c}\text { Variance of } \\
\text { Real House } \\
\text { Price }\end{array}$ & $\begin{array}{c}\text { Average Real } \\
\text { House Price } \\
\text { Inflation }\end{array}$ & $\begin{array}{c}\text { Variance of } \\
\text { Real House } \\
\text { Price Inflation }\end{array}$ \\
\hline Inner London & 10.38 & 1.1386 & 0.3049 & 0.0280 & 0.0174 \\
Outer London & & 1.1316 & 0.2860 & 0.0245 & 0.0156 \\
South East & 19.40 & 1.0974 & 0.2724 & 0.0209 & 0.0159 \\
East Anglia & 4.18 & 1.0645 & 0.2689 & 0.0164 & 0.0170 \\
South West & 9.11 & 1.0937 & 0.2368 & 0.0178 & 0.0128 \\
East Midlands & 7.47 & 1.0798 & 0.2092 & 0.0101 & 0.0118 \\
West Midlands & 9.45 & 1.0489 & 0.1917 & 0.0109 & 0.0107 \\
North West & 10.42 & 1.0394 & 0.1815 & 0.0120 & 0.0097 \\
Yorkshire & 8.91 & 0.9867 & 0.1473 & 0.0028 & 0.0115 \\
Wales & 4.99 & 0.9750 & 0.1327 & 0.0047 & 0.0130 \\
North & 6.32 & 1.0224 & 0.1217 & 0.0051 & 0.0073 \\
Scotland & 9.37 & 1.0021 & 0.0576 & 0.0041 & 0.0026 \\
\hline
\end{tabular}

Source: Nationwide house price indices (1978q1-2000q2).

U.K. households are located) face considerably higher volatility than the average U.K. index. We return to this in the following.

\subsubsection{Differences in Wealth Holdings in Housing and Stock}

In tables 5.8 and 5.9 we report percentiles of net primary housing wealth and stock wealth, in both the United States and the United Kingdom, by home ownership and stock ownership status. Note that in this table and 
Table 5.8

Percentiles of U.K. Net Primary Housing Wealth and Stock Wealth, by

Home Ownership and Stock Ownership Status (BHPS 1995)

\begin{tabular}{|c|c|c|c|c|}
\hline Percentile & $\begin{array}{c}\text { All } \\
(100 \%)\end{array}$ & $\begin{array}{l}\text { Homeowners } \\
\quad(65.6 \%)\end{array}$ & $\begin{array}{l}\text { Stock Holders } \\
\quad(24.0 \%)\end{array}$ & $\begin{array}{c}\text { Homeowners with Stock } \\
\qquad(20.7 \%)\end{array}$ \\
\hline \multicolumn{5}{|c|}{ Net Primary Housing Wealth } \\
\hline Mean & 54.3 & 82.2 & 89.0 & 104.5 \\
\hline 10 & 0.0 & 9.3 & 0.0 & 11.6 \\
\hline 25 & 0.0 & 32.6 & 17.1 & 45.0 \\
\hline 50 & 32.6 & 68.3 & 73.0 & 85.4 \\
\hline 75 & 85.4 & 108.7 & 125.8 & 139.7 \\
\hline 90 & 136.6 & 155.3 & 201.8 & 217.4 \\
\hline 95 & 186.3 & 225.1 & 279.5 & 310.5 \\
\hline \multicolumn{5}{|c|}{ Stock Wealth (lower) } \\
\hline Mean & 7.8 & 11.3 & 32.8 & 35.5 \\
\hline 10 & 0.0 & 0.0 & 0.6 & 0.7 \\
\hline 25 & 0.0 & 0.0 & 2.3 & 2.3 \\
\hline 50 & 0.0 & 0.0 & 9.2 & 9.3 \\
\hline 75 & 0.0 & 1.6 & 31.1 & 38.8 \\
\hline 90 & 13.2 & 23.3 & 77.6 & 93.2 \\
\hline 95 & 41.9 & 60.6 & 139.7 & 155.3 \\
\hline \multicolumn{5}{|c|}{ Stock Wealth (upper) } \\
\hline Mean & 10.3 & 14.8 & 43.5 & 46.5 \\
\hline 10 & 0.0 & 0.0 & 0.8 & 0.8 \\
\hline 25 & 0.0 & 0.0 & 3.1 & 3.1 \\
\hline 50 & 0.0 & 0.0 & 10.9 & 14.0 \\
\hline 75 & 0.0 & 1.6 & 46.6 & 50.5 \\
\hline 90 & 15.5 & 31.0 & 116.4 & 116.4 \\
\hline 95 & 50.5 & 77.6 & 156.8 & 186.3 \\
\hline
\end{tabular}

those that follow, we use the upper bound of household stock wealth in the United Kingdom. Because the United Kingdom has less stock wealth, if anything, differences between the United States and the United Kingdom will be underestimated. For all types of households the distribution of wealth held in the form of primary housing is higher at each point in the United Kingdom than in the United States, although the differences are largest in the bottom three-quarters of the distribution.

In contrast, stock holdings are much higher among American households. In the mid-1990s, the mean value of shares in America was three times as large as in Britain and was about twice as large when considering shareholders only. In both countries, distributions of stock values are highly skewed, with extreme concentrations in 5 to 10 percent of households. But at all points in the distributions, the value of American holdings are multiples of two or three of those held by British households. ${ }^{13}$

13. Banks, Blundell, and Smith (2000) show that the comparison between the 1995 BHPS and the 1984 PSID reveals that, both for the full population of households and for share- 
Table 5.9

Percentiles of U.S. Net Primary Housing Wealth and Stock Wealth, by Home Ownership and Stock Ownership Status (PSID 1994)

\begin{tabular}{lcccc}
\hline Percentile & $\begin{array}{c}\text { All } \\
(100 \%)\end{array}$ & $\begin{array}{c}\text { Homeowners } \\
(62.6 \%)\end{array}$ & $\begin{array}{c}\text { Stock Holders } \\
(34.1 \%)\end{array}$ & $\begin{array}{c}\text { Homeowners with Stock } \\
(27.6 \%)\end{array}$ \\
\hline \multicolumn{5}{c}{ Net Primary Housing Wealth } \\
Mean & 45.2 & 72.1 & 80.5 & \\
10 & 0.0 & 8.2 & 0.0 & 99.7 \\
25 & 0.0 & 22.5 & 10.2 & 34.3 \\
50 & 17.9 & 51.1 & 51.1 & 71.6 \\
75 & 66.5 & 92.0 & 102.2 & 122.7 \\
90 & 125.8 & 153.4 & 184.0 & 204.5 \\
95 & 178.9 & 224.9 & 256.6 & 286.3 \\
& & & Stock Wealth & \\
Mean & 31.0 & 46.1 & 90.5 & 204.8 \\
10 & 0.0 & 0.0 & 1.2 & 2.0 \\
25 & 0.0 & 0.0 & 5.1 & 81.8 \\
50 & 0.0 & 0.0 & 23.5 & 230.0 \\
75 & 6.1 & 20.4 & 66.5 & 409.0 \\
90 & 51.1 & 102.2 & 204.5 & \\
95 & 153.4 & 204.5 & 347.6 & \\
\hline
\end{tabular}

The conditional distributions contained in tables 5.8 and 5.9 hint at a greater separation of stock and housing holdings among British households. Among stockholders, the mean value of stock holdings in the United Kingdom is only $\$ 3,000$ higher if British households are also homeowners. The "effect" of home ownership on stock wealth is much higher in the United States, especially among large stock values.

Tables 5.10 and 5.11 present means and medians of stock and housing wealth by age band in the two countries, split according to whether households have stocks, housing wealth, or both. Looking at the patterns by age, a striking difference emerges. Homeowners in the United Kingdom demonstrate a substantial age gradient in their housing wealth, at both the mean and median. Median net housing wealth for the forty-forty-nineyear-olds is seven times higher than that for the twenty-twenty-nine-yearolds. This gradient is much flatter in the United States, with the corresponding ratio being just over three. The reverse is true for stock wealth-the age gradient of stock wealth for stock owners in the United Kingdom is

holders only, the distribution of share values held by households are virtually identical. That is, after the stock market surge in both countries, British households had stock wealth similar to American households ten years earlier. In the early 1980s, however, we know that in light of the subsequent extremely large increase in share ownership, British households' stock holdings were considerably smaller than their American counterparts. This initial condition difference between the two countries would have profound impacts on wealth distributions by the mid-1990s. 


\begin{tabular}{|c|c|c|c|c|c|c|c|}
\hline \multirow[b]{2}{*}{ Age Range } & \multirow{2}{*}{$\begin{array}{c}\begin{array}{c}\text { All } \\
(100 \%)\end{array} \\
\text { Mean }\end{array}$} & \multicolumn{2}{|c|}{$\begin{array}{l}\text { Homeowners } \\
(65.6 \%)\end{array}$} & \multicolumn{2}{|c|}{$\begin{array}{l}\text { Stock Holders } \\
\quad(24.0 \%)\end{array}$} & \multicolumn{2}{|c|}{$\begin{array}{c}\text { Homeowners with } \\
\text { Stock }(20.7 \%)\end{array}$} \\
\hline & & Mean & Median & Mean & Median & Mean & Median \\
\hline \multicolumn{8}{|c|}{ Housing Wealth } \\
\hline $20-29$ & 6.3 & 16.7 & 10.9 & 5.6 & 3.1 & 10.3 & 11.6 \\
\hline $30-39$ & 26.8 & 38.7 & 31.0 & 36.6 & 24.8 & 43.5 & 31.0 \\
\hline $40-49$ & 63.3 & 82.7 & 68.3 & 95.2 & 69.9 & 104.5 & 74.5 \\
\hline $50-59$ & 83.7 & 109.6 & 96.3 & 122.2 & 112.9 & 131.2 & 121.1 \\
\hline $60-69$ & 82.1 & 119.5 & 93.2 & 117.4 & 105.6 & 143.9 & 132.0 \\
\hline $70+$ & 57.4 & 104.2 & 86.9 & 112.0 & 100.9 & 139.0 & 108.7 \\
\hline \multicolumn{8}{|c|}{ Stock Wealth (lower) } \\
\hline $20-29$ & 1.5 & 1.8 & 0.0 & 10.2 & 4.7 & 9.5 & 3.7 \\
\hline $30-39$ & 3.9 & 5.1 & 0.0 & 15.0 & 5.4 & 16.0 & 5.8 \\
\hline $40-49$ & 6.1 & 7.5 & 0.0 & 23.2 & 7.8 & 24.1 & 7.8 \\
\hline $50-59$ & 11.0 & 13.5 & 0.0 & 32.4 & 9.3 & 32.6 & 10.9 \\
\hline $60-69$ & 15.3 & 21.4 & 0.0 & 55.4 & 20.2 & 65.5 & 38.8 \\
\hline $70+$ & 8.2 & 15.4 & 0.0 & 50.7 & 10.1 & 57.0 & 115.5 \\
\hline \multicolumn{8}{|c|}{ Stock Wealth (upper) } \\
\hline $20-29$ & 1.6 & 2.0 & 0.0 & 10.7 & 4.7 & 10.2 & 3.7 \\
\hline $30-39$ & 4.7 & 6.2 & 0.0 & 17.9 & 6.2 & 19.3 & 6.2 \\
\hline $40-49$ & 7.5 & 9.3 & 0.0 & 28.5 & 9.3 & 29.6 & 9.3 \\
\hline $50-59$ & 18.0 & 20.0 & 0.0 & 53.0 & 15.5 & 48.1 & 15.5 \\
\hline $60-69$ & 19.5 & 27.2 & 0.0 & 70.0 & 30.0 & 83.3 & 50.5 \\
\hline $70+$ & 9.8 & 18.9 & 0.0 & 60.8 & 12.4 & 69.7 & 15.5 \\
\hline
\end{tabular}

Table 5.11

U.S. Net Primary Housing Wealth and Stock Wealth, by Age, Home Ownership, and Stock Ownership Status (PSID 1994)

\begin{tabular}{|c|c|c|c|c|c|c|c|}
\hline \multirow[b]{2}{*}{ Age Range } & \multirow{2}{*}{$\begin{array}{c}\begin{array}{c}\text { All } \\
(100 \%)\end{array} \\
\text { Mean }\end{array}$} & \multicolumn{2}{|c|}{$\begin{array}{l}\text { Homeowners } \\
\quad(62.6 \%)\end{array}$} & \multicolumn{2}{|c|}{$\begin{array}{l}\text { Stock Holders } \\
(34.1 \%)\end{array}$} & \multicolumn{2}{|c|}{$\begin{array}{c}\text { Homeowners with } \\
\text { Stock }(27.6 \%)\end{array}$} \\
\hline & & Mean & Median & Mean & Median & Mean & Median \\
\hline \multicolumn{8}{|c|}{ Housing Wealth } \\
\hline $20-29$ & 9.9 & 36.4 & $15.3^{\circ}$ & 23.6 & 0.0 & 55.0 & 18.4 \\
\hline $30-39$ & 21.4 & 40.5 & 28.6 & 33.7 & 21.5 & 46.1 & 33.7 \\
\hline $40-49$ & 43.1 & 61.3 & 48.4 & 80.7 & 48.1 & 96.8 & 63.4 \\
\hline $50-59$ & 81.1 & 100.0 & 62.4 & 114.5 & 76.7 & 128.6 & 81.8 \\
\hline $60-69$ & 86.0 & 104.0 & 81.8 & 132.1 & 102.2 & 139.1 & 112.5 \\
\hline $70+$ & 60.0 & 84.3 & 71.6 & 92.2 & 76.7 & 108.2 & 91.0 \\
\hline \multicolumn{8}{|c|}{ Stock Wealth } \\
\hline $20-29$ & 2.4 & 4.6 & 0.0 & 12.6 & 3.6 & 15.5 & 4.1 \\
\hline $30-39$ & 12.5 & 20.1 & 0.0 & 40.2 & 10.2 & 47.0 & 11.2 \\
\hline $40-49$ & 25.4 & 32.9 & 0.0 & 62.0 & 21.5 & 67.7 & 25.6 \\
\hline $50-59$ & 51.1 & 61.0 & 1.0 & 108.2 & 35.8 & 117.6 & 35.8 \\
\hline $60-69$ & 88.7 & 105.6 & 0.0 & 213.0 & 61.3 & 221.2 & 61.3 \\
\hline $70+$ & 33.4 & 41.1 & 0.0 & 123.3 & 51.1 & 127.9 & 51.1 \\
\hline
\end{tabular}


extremely shallow, ${ }^{14}$ whereas in the United States stock wealth rises by a factor of almost ten for stock holders aged fifty in comparison to those aged twenty-twenty-nine. Looking at just those who own both homes and stocks, the differences still emerge. It is these differences that we will explore in more detail later in the paper and that motivate the design of our modeling exercise.

\subsection{A Model of Housing Tenure Choice and Portfolio Decisions}

\subsubsection{The Demand for Housing Services}

In the simplest model, housing demand is purely a function of family size. It will therefore increase over the early period of the adult life cycle as family size increases. In figure 5.4, we present profiles for house size, with each line representing a thirty-year time series of the average number of rooms for a year-of-birth cohort over the time period 1968-98. The figure shows that in the United Kingdom there is a strong increase in house size, as measured by the number of rooms, as the head of household grows older, flattening out around age forty but rising steeply from the twenties to the thirties. For this reason we can frame our discussion in terms of a stylized model with three stages in an early adult life cycle: leaving home, living as a couple without children, and living as a couple with children. There is also little evidence of strong cohort effects during the early part of the adult life cycle, as evidenced by the lack of vertical differences between each cohort's profiles up to age forty. Hence this rise is the same whether we look at the individual date of birth cohorts, as in the figure, or pool across cohorts.

In general, housing demand will also depend on the unit price of services, the level of (expected) wealth, and the degree of uncertainty over all these variables. It is likely that demand for housing services is price inelastic. Consequently, expenditure on housing services will be increasing in the price of housing services. According to our numbers, the median value of a U.S. owned home in 1994 is about 14 percent less than the median price (value) of a U.K. owned home. Unless we think that there is 14 percent more utility involved, this is evidence of a higher unit price in the United Kingdom. A higher unit price in the United Kingdom will induce a higher level of expenditure, conditional on all the other factors.

\subsubsection{The Choice of Housing Tenure}

At the start of the adult life cycle, housing tenure decisions occur in two stages: first, a choice of when to leave the parental home and second,

14. Note that for stock wealth the mean profiles are substantially affected by a cluster of extremely high-wealth young individuals. Age gradients at all but the 99th percentile and above display the same increasing pattern as the median. 


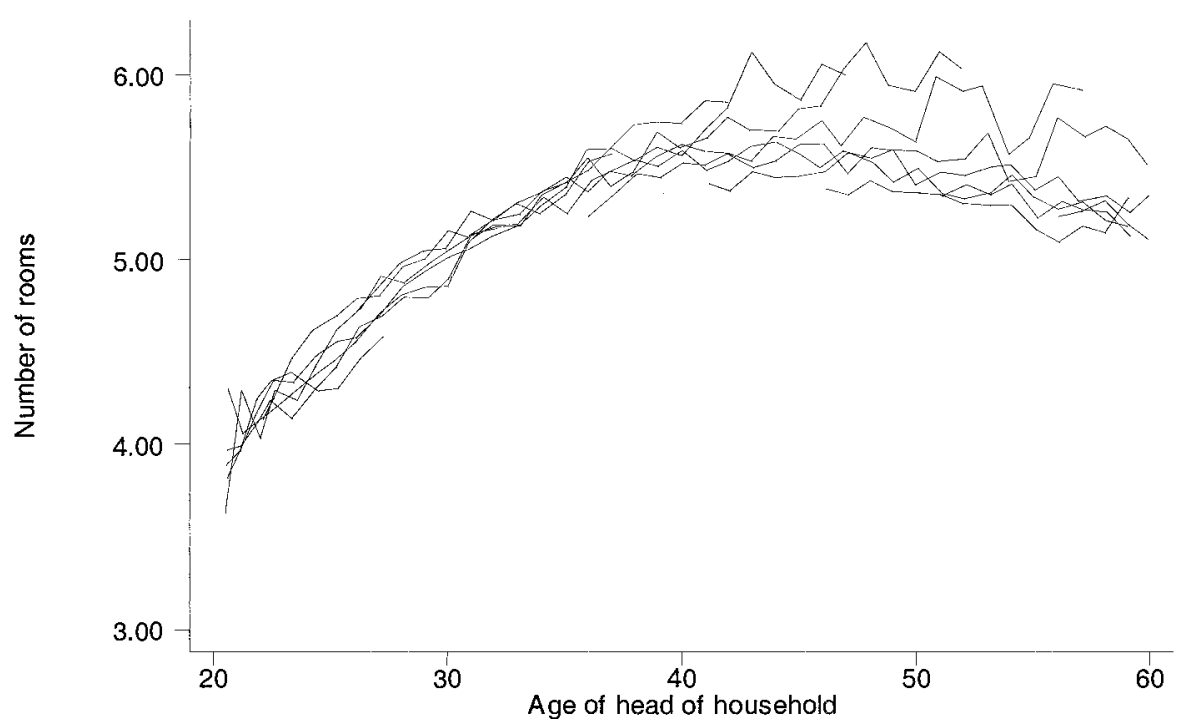

Fig. 5.4 Average number of rooms over the life cycle, by age and cohort, from FES data (1968-1998).

whether to rent or to buy. Strictly speaking, the latter is not a portfolio decision because, if a house is bought and continuously remortgaged, there is no necessity to hold any housing equity. Yet, ownership is a prerequisite for securing housing equity, and so the decision to own may be influenced by portfolio choices as well as pure service-flow considerations. A house may also be owned without any desire to accumulate housing equity simply because it is an efficient way to achieve a desired flow of housing services. For a household with little expected mobility and heterogeneity of tastes, owning can be the least costly way of achieving a desired level of housing service.

Young households who first decide to rent remain potential purchasers of a starter home as soon as they are able to secure a down payment. In the decision to leave the parental home, credit constraints will also play an important role as such constraints are typically binding on young adults who must accumulate sufficient wealth to meet down payment and collateral requirements. Consequently, the income of the young will be important, and the volatility of incomes of young people rather than per capita income per se, will be critical in generating swings in housing transactions. ${ }^{15}$ Higher down payments lengthen the time required to build up enough wealth to satisfy lenders and will make first-time home buyers older, on average. Sim-

15. This also accords with the property ladder model of Ortalo-Magne and Rady (1998), which views the housing market as a step-function. 
ilarly, inadequate rental markets may delay the age at which one leaves the parental home but lower the age at which one buys the first home. This last point is explored, using the BHPS data used in our analysis, in Ermisch (1999) who finds empirical support for the economic conditions of the housing market relating to the household formation choices of the young in Britain.

In light of the data in figure 5.4 and of empirical and theoretical models of housing market dynamics (see, e.g., Di Salvo and Ermisch 1997 and Ortalo-Magne and Rady 1998, respectively), the initial home purchase is best seen as the first step in a property ladder. If there is some job or demographic mobility expected then, because of lower transaction costs, the rental market may provide a less costly way of choosing an optimal path for housing services. If house prices are variable, the rental market may also provide a contract insuring against some of that risk. But by leaving equity in their home, first-time homeowners are partially self-insuring against price fluctuations in the housing market. While a price increase will raise the price (and required down payment) on the second home, the price of the first home is also increasing, providing additional resources for that now larger down payment. A symmetric argument obtains during periods of housing price declines.

As incomes and family sizes grow, these now slightly older young adults hope to buy a larger, more expensive home. The time interval between these purchases is once again governed by the length of time it takes to secure the larger down payment needed on the bigger house. Low down payment requirements will shorten the interval between home purchases. In addition, any capital gains on the first house may be used to help buy the second. Capital gains during booms will tend to shorten the time interval between the first and second home purchase, whereas capital losses during downturns will lengthen this interval.

\subsubsection{House Price Uncertainty and the Choice between Stock and Housing Equity}

Each household has a desired level of total wealth. This level will depend on expected future income and consumption streams as well as the returns on assets. First, consider the portfolio demand for housing equity. If house prices are variable and uncertain then, given the increased demand over the early part of the life cycle, housing equity will be an important source of insurance against house price risk. The larger the uncertainty in house prices and the steeper the demand over the life cycle, the more important is the insurance aspect of housing equity.

Conditional on being an owner, therefore, the higher the level of house price uncertainty the larger the demand to pay down the mortgage and to hold wealth in housing equity. This will be particularly the case for households early in their life cycle as they anticipate stepping up the property 
ladder. It would make little sense for risk-adverse young households who face housing price volatility to invest their assets in the stock market even if stock price and housing price risks are uncorrelated.

The tax treatment of mortgage repayments will also influence the level of mortgage held and the desire to hold equity in housing. A tax advantage to borrowing via a mortgage will make it optimal to consume more housing services and to use ownership as a vehicle for that consumption but not necessarily to pay down the mortgage. Rather, it might be optimal to invest in another risky asset rather than pay down the outstanding mortgage or even to remortgage a housing equity capital gain.

\subsubsection{The Supply of Housing Services}

There are two aspects of the supply of housing services that are central to our model. First, a more inelastic supply will induce a larger sensitivity of house prices to fluctuations in demand, in particular to fluctuations in the income of young, first-time buyers. The second aspect relates to the rental market. Imperfections and/or regulation of the private rental market may make it difficult for the young to use rental housing as the step between leaving the parental home and acquiring a house. The rental market may also be dominated by the public sector in which case the allocation mechanism may be less sensitive to the demand of young households.

A consequence of inelastic demand is that expenditure on housing services will be increasing in the price of housing services.

\subsubsection{Model Predictions}

The model predictions for the United Kingdom relative to the United States as households move through their early life-cycle profile are clear. The demand for housing services will increase as family size increases. Consider the three stages of our stylized life-cycle profile: leaving home, living independently without children, and living with children. The model predicts that the level of owner occupation at the second stage should be lower in the United States relative to the United Kingdom if the deposit and mobility motivations dominate the tax advantage. This is reinforced by the higher house price volatility in the United Kingdom which makes owner occupation more likely for those in the second stage of this life-cycle profile.

This prediction could also be rationalized by an inefficient rental market in the United Kingdom. However, the arguments also suggest that the United Kingdom would have a higher level of housing equity for volatility reasons but that this would be reduced once full household size is reached at stage three in the early life-cycle profile because the positive volatility effect would disappear. Other things being equal, the tax advantage in the United States would make households more likely to be owners in the 
United States and less likely to pay down capital—and less likely to accumulate housing equity.

The higher volatility in the United Kingdom increases the desire to hold housing equity in the United Kingdom for those households in the second stage of their demographic profile, that is, those who expect to increase their family size. In turn, this increases the desire to be an owner for such households in the United Kingdom. We expect more owners and a higher paying down of outstanding housing debt in the United Kingdom and a higher level of housing equity in the United Kingdom. The latter, but not the former, of these is predicted by the tax advantage.

\subsection{The Housing Market and Income Risk of the Young}

\subsubsection{The Housing Market}

Our model on housing markets places great weight on the role of young households and on the role of housing and stock in portfolios over the life cycle. To evaluate whether the young merit such an emphasis, we examine individuals who purchased a new home between waves of the PSID and BHPS samples. Across all ages, about one in twenty household heads in both countries are observed to have bought a new home since the previous wave of the panel. It is also clear that young people were far more active in the housing market. For example, 12 percent of British household heads between the ages of twenty and twenty-nine had bought a new home during the last year. The comparable number in the United States was 9 percent.

Table 5.12 lists the age distribution of household heads who purchased a home between the annual waves of each survey. ${ }^{16}$ Besides describing all home buyers, these data are stratified by whether household heads were "first-time" buyers or "repeat" buyers. Repeat buyers represent those who had lived in a home that they owned before this new purchase, whereas first-time buyers were not living in a home that they had personally owned right before this new purchase. ${ }^{17}$

Consistent with our view that they constitute the active part of the housing market, new home buyers are much younger than the average homeowner. ${ }^{18}$ Moreover, the typical purchaser of a new home is a good deal younger in the United Kingdom than in the United States. For example, 63 percent of all new buyers in the United Kingdom are less than forty years old with a median age of thirty-five. The comparable numbers for the

16. To provide adequate sample sizes on home buyers, the data were pooled across years.

17. More precisely, "first-time" buyers consist of those who lived in a rental house in the previous survey wave and those who lived in an owned home with their parents.

18. For example, in 1994 the mean age of all homeowners was 50.4 in the United Kingdom and 51.3 in the United States. 
Table 5.12

Age Distribution of Home Buyers (\%)

\begin{tabular}{lcrrrrrrr}
\hline & \multicolumn{2}{c}{ All Buyers } & & \multicolumn{2}{c}{ First Time Buyers } & & \multicolumn{2}{c}{ Repeat Buyers } \\
\cline { 2 - 3 } Age & U.K. & U.S. & & U.K. & U.S. & & U.K. & U.S. \\
\hline $20-29$ & 30.1 & 21.5 & & 47.4 & 31.6 & & 15.7 & 9.9 \\
$30-39$ & 32.5 & 35.8 & & 26.8 & 36.2 & & 37.3 & 35.3 \\
$40-49$ & 16.0 & 19.8 & & 9.7 & 16.4 & & 21.3 & 23.7 \\
$50-59$ & 9.2 & 9.8 & & 5.3 & 7.6 & & 12.4 & 12.3 \\
$60-69$ & 5.5 & 7.5 & & 3.6 & 4.6 & 7.1 & 10.8 \\
$70+$ & 6.7 & 5.7 & & 7.2 & 3.6 & 6.2 & 8.1 \\
Total & 100.0 & 100.0 & & 100.0 & 100.0 & & 100.0 & 100.0 \\
Median & 35.0 & 37.0 & & 30.0 & 34.0 & & 38.0 & 41.0 \\
Mean & 39.3 & 41.1 & & 35.9 & 37.6 & & 42.2 & 45.1 \\
\hline
\end{tabular}

Notes: Rows for each country should add up to 100.0. Sample comprised of home buyers who are heads in period $t$; all years pooled.

United States are 57 percent and a median age of thirty-seven. The differences between the two countries are most striking among those household heads between the ages of twenty and twenty-nine, who constitute 30 percent of all new U.K. buyers compared to 22 percent in the United States.

First-time buyers are especially young, with median ages of only thirty (United Kingdom) and thirty-four (United States). Household heads less than thirty years old comprise almost half (47 percent) of all first time buyers in Britain, much higher than the comparable U.S. proportion of about one-third (32 percent). Not surprisingly, repeat buyers are somewhat older in both countries, but even here the median ages are only thirty-eight (United Kingdom) and forty-one (United States). More than half of repeat home buyers in the United Kingdom are less than forty years old.

Age is one dimension in which new home buyers differ in the two countries. ${ }^{19}$ Table 5.13 tries to illuminate an additional dimension by listing prevalence rates of new owners by their joint ownership and headship status in the previous survey wave. A similar fraction of new buyers in both countries had owned their own home in the prior wave. The principal difference emerges in the third column where there exists a far greater fraction of American households who made a transition from renting a place of their own to buying one. These intercountry differences are especially large among young people (aged twenty-twenty-nine). In particular, 64 percent

19. As documented in section 5.3, over recent years the relative tax status of housing and stock wealth has been changing markedly. Broadly speaking, both assets are now taxed neutrally with respect to current consumption, while in the past housing was tax-favored, and wealth held in the form of stocks was tax-penalized. In contrast, since the introduction of IRAs both assets have received a relatively stable tax treatment in the United States. 
Make Up of New Homebuyers, by Age

\begin{tabular}{lccccc}
\hline & \multicolumn{5}{c}{ Status in Previous Year } \\
\cline { 2 - 4 } Age Range & $\begin{array}{c}\text { Head and } \\
\text { Owner }\end{array}$ & $\begin{array}{c}\text { Nonhead in an } \\
\text { Owned House }\end{array}$ & $\begin{array}{c}\text { Head and } \\
\text { Renter }\end{array}$ & $\begin{array}{c}\text { Nonhead in a } \\
\text { Renter House }\end{array}$ & All \\
\hline United Kingdom & & & & & \\
20-29 & 0.196 & 0.380 & 0.250 & 0.174 & 100.0 \\
30-39 & 0.530 & 0.132 & 0.261 & 0.077 & 100.0 \\
40-49 & 0.615 & 0.125 & 0.210 & 0.051 & 100.0 \\
50-59 & 0.639 & 0.102 & 0.252 & 0.007 & 100.0 \\
60-69 & 0.625 & 0.080 & 0.250 & 0.045 & 100.0 \\
$70+$ & 0.449 & 0.065 & 0.467 & 0.019 & 100.0 \\
United States & 0.202 & 0.125 & 0.635 & 0.038 & 100.0 \\
20-29 & 0.439 & 0.030 & 0.517 & 0.014 & 100.0 \\
$30-39$ & 0.538 & 0.023 & 0.422 & 0.017 & 100.0 \\
$40-49$ & 0.575 & 0.010 & 0.396 & 0.019 & 100.0 \\
$50-59$ & 0.657 & 0.015 & 0.320 & 0.008 & 100.0 \\
$60-69$ & 0.639 & 0.026 & 0.329 & 0.005 & 100.0 \\
$70+$ & & & & & \\
\hline
\end{tabular}

Note: Sample comprised of home buyers who are heads in period $t$; all years pooled.

of new buyers in this age group in the United States were previously household heads who were renters. The comparable British figure is only onequarter. The counterweight is the large fraction of young home buyers in Britain who were not heads of household in the prior year ( 55 percent in the United Kingdom compared to 16 percent in the United States). These young British nonhousehold heads were more than twice as likely to live in an owned as opposed to a rented home - it was simply not a home that they owned.

Among those who had lived previously in an owned home, the dominant situation for those between the ages of twenty and twenty-nine was that they departed the parental home. While this is true for both countries, this is a far larger group of young people in the United Kingdom than it is in the United States. A key difference between the two countries concerns what happens when a young person first leaves the parental home. Across the years we examined, about one-fifth of British adults aged twentytwenty-nine who were living in the parental home moved out the next year. The U.S. number is only slightly larger (about one-fourth). While the likelihood of leaving the parental home was roughly similar, where these British and American young adults went could not have been more different. This is illustrated in table 5.14, which shows that almost half of all young adults aged twenty-twenty-nine in Britain who left the parental nest bought their own home. In sharp contrast, this fraction is only 18 percent in the United States. While much smaller numbers are making this transition among 
Table 5.14

Proportion of Those Moving Out of Family Home Who Become Owners, by Age

\begin{tabular}{lcc}
\hline Age Range & United Kingdom & United States \\
\hline 20-29 & 0.466 & 0.180 \\
$30-39$ & 0.557 & 0.231 \\
All ages & 0.486 & 0.191 \\
\hline
\end{tabular}

Note: Sample comprised of all adults who are child of head in $t-1$ and not child of head in $t$; all years pooled.

those aged thirty-thirty-nine, the differences in the type of transition between the two countries remain. ${ }^{20}$

The data in this section document the following important differences between new home buyers in the United Kingdom and the United States. New home buyers are disproportionately very young adults with a particularly pronounced tilt toward the young in Britain. When they leave their parents' home, Americans first tend to live in rental housing either on their own or with their spouse or partner. No doubt due to difficulties in the British rental market, when British youth leave their parents they tend to skip over this intermediate step and go immediately on to purchasing their own house. Finally, these trends have interacted with massive compositional changes in household population so that increasing fractions of young homeowners are not currently married.

\subsubsection{Income Risk}

Our emphasis on the young also points to a potentially important role for income risk in this model. There are two aspects of income risk that will be useful to distinguish. The first is the systematic variation in aggregate first-time buyer income or shocks to income. As we noted previously, it is this that generates variation in the demand for first-time purchases. The second possible measure of income variance is the level of within-period income risk for each age group. We focus on the former since the latter will act as background risk and will only indirectly affect the demand curve

20. Another key demographic phenomenon - the delay, decline, and disruption of marriage, especially among the young — was also affecting the attributes of homeowners. In 1969, 98 percent of British home owners less than thirty years old were married. Thirty years later, one-third of young British home owners were not currently married. These rates currently appear similar within age groups in the two countries, but because there are more young homeowners in Britain, there are far more unmarried homeowners there. This large and growing fraction of young home owners who are not currently married may be another important element of the story. One impact of marriage is that it is an individual income risk reducing institution as one partner insures the other against the vagaries of life. With increasing numbers of young householders not currently married, they may be exposed to more income risk even if the structure of income risk by age did not change. 
through risk aversion. A higher level of the first will create fluctuations in the price of housing provided supply is inelastic.

To investigate this we need to examine whether the variation of the agespecific aggregate shocks is larger for the young. The framework we adopt follows Banks, Blundell, and Brugiavini (2001) and separates aggregate from idiosyncratic risk. To estimate the aggregate variance for each age band, we regress average log income for each cohort on its lagged value for the same cohort and a list of changes in observable demographic characteristics. We then compute the variance of the time- and cohort-specific income shocks from this regression for each age group. The results of this regression using the repeated cross sections from the U.K. Family Expenditure Survey (FES) (1978-99) are presented in table 5.15.

In a simple liquidity constrained model, the variance of income itself, rather than the variance of income shocks, would determine fluctuations in demand. A comparison of the two measures of the aggregate variance for broad age bands in the United Kingdom is presented in the first two columns of table 5.16. For both measures there is a steep decline in aggregate income variation as we move from households whose heads are in their twenties to those households where the heads are in the thirties age band.

Table 5.15 Log Income Model for the United Kingdom: Quarterly Income by Cohort (1968-1992)

\begin{tabular}{lcc}
\hline Variable & Coefficient & Standard Error \\
\hline Log income $(t-1)$ & 1.0070 & 0.0088 \\
$\Delta$ number employed & 0.1277 & 0.0500 \\
$\Delta$ number adults & 0.7455 & 0.0344 \\
$\Delta$ number children & 0.0534 & 0.0288 \\
$\Delta$ number female & -.4004 & 0.0318 \\
Regions & Yes & \\
Seasonals & Yes & \\
Sargan & $17.07(3)$ & \\
GR^2 & 0.9178 & 0.0049 \\
\hline
\end{tabular}

Notes: IV estimation using lagged variables as instruments. Household income equivalized by the number of adults.

Table 5.16 Measures of the Variance of Log Income in the United Kingdom, by Age Group (1968-1992)

\begin{tabular}{lccc}
\hline Age & $\begin{array}{c}\text { Aggregate Variance } \\
\text { of Income }\end{array}$ & $\begin{array}{c}\text { Aggregate Variance } \\
\text { of Income Shocks }\end{array}$ & $\begin{array}{c}\text { Within Age Group } \\
\text { Income Variance }\end{array}$ \\
\hline $20 \mathrm{~s}$ & 0.0263 & 0.0074 & 0.2301 \\
$30 \mathrm{~s}$ & 0.0155 & 0.0034 & 0.2362 \\
$40 \mathrm{~s}$ & 0.0185 & 0.0049 & 0.2713 \\
\hline
\end{tabular}


Note that the level of income variation rises systematically over time, especially in the 1980s, so that younger cohorts face a higher aggregate variation than older cohorts did at the same age. Finally, note that our measure of risk for the young may be an underestimate because the young will presumably also face more risk as a result of uncertainty about future demographics and household formation.

\subsection{How Well Does the Model Explain the Data?}

The model developed in section 5.4 was motivated by a number of facts relating to housing tenure choice, to housing equity, and to the stock of wealth holdings by households over their life cycle in the United Kingdom and the United States. In this section we ask whether the model can provide a convincing explanation and whether it can do better than other competing explanations.

\subsubsection{Implications of the Model}

The principal implications of our model stem from the significantly higher volatility of house prices in the United Kingdom. This starting point is fundamental, and we have two underlying explanations for it. First, the supply of housing is likely to be more inelastic in the United Kingdom, in part due to the greater population density there. This is most clearly seen in the dominance of the greater London area in the British housing market. Around 30 percent of all homes in England are located within the Southeast (including Greater London). Not only is the available space limited there, but new housing construction or conversion is heavily regulated and costly to build. This more inelastic supply implies that for any given demand side fluctuations, housing prices will be more volatile in the United Kingdom than in the United States.

Second, house prices are more sensitive to the variation in first-time buyer demand and therefore the volatility of first-time buyer incomes. Because new British home buyers are younger and therefore positioned on the more volatile part of the income risk-age curve, income fluctuations inducing demand side swings will also contribute to the greater price volatility in the British housing market.

In addition to more volatile prices, down payment requirements are less onerous in the United Kingdom, and the rental market is less efficient. In our model, these conditions all conspire to lead young U.K. households to move into owner occupation rather than to rent and to do this at an earlier age. This pattern of home ownership is borne out by the data. We find a significantly lower use of the rental market in the United Kingdom among younger households and a much higher probability in the United Kingdom of transiting from parental home to owner occupation. Of those adults 
aged twenty-twenty-nine observed to leave the parental home in the BHPS, 46.6 percent became owner-occupiers directly, as opposed to only 15.0 percent for their PSID counterparts. Although the group is much smaller, similar differences pertain for the thirty-thirty-nine age group.

Our model also had implications for portfolio choice. The higher house price volatility in the United Kingdom makes it optimal for those young households who expect to move up the property ladder to hold housing equity. Young homeowners in the United Kingdom who plan to upgrade their housing by purchasing a larger, newer home as their incomes and families expand may face considerable housing price risk. One method of self-insuring against housing price volatility would be to maintain a large fraction of household wealth in housing equity thereby matching possible variation in the value of one's current home with the price of any desired home upgrade. ${ }^{21}$ In contrast, a quite risky strategy among young homeowners would be to hold much of their wealth in stock. Even if housing price and stock price risks are uncorrelated, a downturn in the equity market could make it quite difficult for young homeowners (who have limited amounts of household wealth) to reach their down payment goals for the new home.

For young U.K. households facing higher house price risk and lower down payment requirements, the model predicts that they enter the housing owning market earlier, cover a very large percentage of the house price by mortgage, and then pay down the mortgage as a saving instrument for future movements up the property ladder. Early in their adult life cycle we would expect to see a higher proportion of young owner-occupier households in the United Kingdom. At this point they would have little equity in housing and hold relatively large mortgages. But as they move through the early part of their adult life cycle they would, rather, accumulate housing equity than stock. Consequently, we predict that compared to the United States, in the United Kingdom age gradients in housing equity will be steeper and in stock equity less in the early part of the life cycle. From figure 5.4 we might expect this comparison to be particularly strong in the twenties and thirties and then to dampen out in the forties and fifties as the property ladder reaches a plateau.

The housing and stock wealth numbers reported in tables 5.10 and 5.11 would appear to be most relevant for testing these predictions. Tables 5.10 and 5.11 show, as predicted, that U.K. households indeed have a much steeper gradient in the accumulation of wealth in housing equity. The strong gradient for U.K. households is evident in both the mean and the

21. The downside of this risk, the so-called "negative equity" phenomenon that was widespread in the late 1980s and early 1990s, is only a problem if households cannot meet the monthly mortgage payments and are forced out of the market by repossession. 
median of housing wealth in the first panel of table 5.10. The model also implies that the gradient should be even steeper among homeowners, especially those facing high housing price risk. Mean housing wealth rises by a factor of two between the twenties and thirties and then again by the same factor between the thirties and forties for homeowners in the United Kingdom. The reverse is true for stock wealth. Compared to the United States, the United Kingdom shows little gradient in stock wealth for those households early in their adult life cycle. For stock, due to a few large outliers, the median is probably a more robust measure, but even for the median there is little evidence of a gradient in the United Kingdom. In the United States the gradient in stock wealth is even more striking than it is for housing wealth in the United Kingdom.

\subsubsection{Biases in Age Gradients for the Portfolios of the Young}

There are potential problems with our reliance on the data in tables 5.10 and 5.11. First, cohort effects that we have seen are quite real in housing, and equity markets may confound them. Second, they describe the pattern of wealth holdings by age of household heads and many young adults are in households headed by their parents and thus appear in households with older heads.

\section{Cohort Effects}

The data in tables 5.10 and 5.11 are cross-sectional age profiles and may be contaminated by year and cohort effects. If cohort and time effects are the same across the two countries, our comparisons of age profiles may be less affected by this issue than for each individual country age profile. Yet the evidence in tables 5.2 and 5.6-listing ownership age profiles by country and year - suggests this may not be the case.

There are two types of cohort-year effects that may well affect our comparisons. The first are unique events that differentially affected the incentives to own homes or stocks in the two countries. The second results from the possible contamination of home and stock equity age profiles due to capital gains.

We first examine the impact of capital gains. For stocks, average rate of returns have been high and approximately the same in both countries, but there remains a possibility that middle-aged American cohorts benefited by being differentially exposed to the stock market (in comparison to the United Kingdom) in the mid-1980s. Fortunately, because questions are included on new stock purchases and sales we are able, in the United States data, to separate out that part of wealth accumulation in stock that is due to capital gains. To examine the impact of capital gains, we list in the first column of table 5.17 the cross-sectional holdings of stock wealth by age in the United States in 1984. The next column labeled shows the actual stock wealth of these 1984 age groups ten years later. The large within-cohort in- 
creases in stock wealth are certainly suggestive of significant capital gains in stocks. While these adjusted profiles indicate a much less steep pure lifecycle increase in stock wealth, even the capital gains adjusted data for the United States exhibit a larger age gradient than the unadjusted U.K. age gradient. Because the British stock age gradient is also exaggerated by capital gains, we conclude that the steeper U.S. age gradient for stock wealth is not solely a consequence of capital gains in stocks. For housing, however, the time series of returns suggests that over the period as a whole (particularly to 1994) returns were similar in both countries but more volatile in the United Kingdom.

In addition to the impact of differential capital gains, there are other cohort-year effects that differentially impact both stock and housing markets in the United Kingdom. However, these year effects are specific to a very narrow time period, allowing us to control for their impact. For example, the large increase in stock ownership rates in the United Kingdom due to the flotation of national industries was concentrated during the time period 1984-89. By limiting our comparisons to the post-1989 period, we can minimize the impact of this effect. We do so in table 5.18 by listing in the first column 1989 age profiles of stock ownership in both countries. In the adjacent column are listed the ownership rates of these age groups ten

Table 5.17

Fraction of U.S. Change in Stock Wealth between 1984 and 1994 Due to Capital Gains

\begin{tabular}{lrcc}
\hline Age Range & 1984 & $\begin{array}{c}\text { Realized } \\
1994\end{array}$ & $\begin{array}{c}\text { Realized Adjusted for } \\
\text { Capital Gains }\end{array}$ \\
\hline $20-29$ & 0.9 & 12.5 & 7.0 \\
$30-39$ & 4.8 & 25.4 & 15.1 \\
$40-49$ & 8.7 & 51.1 & 23.7 \\
$50-59$ & 19.6 & 88.7 & 42.3 \\
\hline
\end{tabular}

Table 5.18

Life-Cycle Changes in Stock Ownership (1989-1999)

\begin{tabular}{lll}
\hline Age Range & 1989 & 1999 \\
\hline United Kingdom & & \\
$20-29$ & 0.102 & 0.211 \\
$30-39$ & 0.187 & 0.258 \\
$40-49$ & 0.262 & 0.333 \\
$50-59$ & 0.312 & 0.351 \\
United States & & \\
$20-29$ & 0.160 & 0.350 \\
$30-39$ & 0.258 & 0.412 \\
$40-49$ & 0.358 & 0.486 \\
$50-59$ & 0.374 & 0.456 \\
\hline
\end{tabular}


years later. In all cases, there was a much more rapid buildup in stock ownership in the United States compared to the United Kingdom.

\section{Household Composition}

So far we have been considering age profiles of housing and stock wealth computed by the age band of the head of the household. The head of the household is in turn defined by the owner of the property, and in the case of joint ownership, the oldest of the joint owners. Given the higher frequency of young adults living in households with older heads in the United Kingdom, tables 5.10 and 5.11 could display serious differential bias in the age pattern of housing and stock holdings of the United Kingdom relative to the United States. These biases apply to a considerably wider set of problems and relationships of interest than this one alone.

There are two potential biases due to household composition in looking at differences in life-cycle age profiles across countries. The very notion of a household (defined by the age of the head) results in the consideration of a selected sample. In both countries there will be young adults, at the beginning of their life cycles, who are still in the parental home or in other nonspousal living arrangements, many of whom will not be picked up in our calculations in the appropriate age band. To the extent that this group is differentially sized in the two countries the age profiles will be differentially affected.

Table 5.19 examines this issue by considering all adults in each age band (as opposed to just household heads) and looking at the distribution of relationships to the head of the household in which they live. Roughly onequarter of adults aged twenty-twenty-nine in each country are still living with their parents (i.e., they are children of the head). But this is where the similarities end. A higher proportion of young adults in the United Kingdom are married or cohabiting with the household head, considerably fewer adults in the United Kingdom are actually household heads, and considerably more are in "other" arrangements, where among the young this group is predominantly made up of nonrelatives.

This means that the country-specific age profiles may well be influenced by the fact that when working at the household level we do not count many young individuals at the start of their life cycles. These children of household heads will crop up instead in our tables as members of the households aged forty-forty-nine or fifty-fifty-nine. These omitted young adults from the early age bands will tend to have lower housing (in fact zero) and stock wealth so that age gradients will tend to be understated.

Table 5.19 indicates a second bias - there are substantially more single heads of household among the young in the United States than in the United Kingdom. Individuals in single and married households are treated quite differently in a household unit analysis. The combined assets of the 
Table 5.19

All Adults: Distribution of Relationships to Head of Household, by Age (\%)

\begin{tabular}{lcccccc}
\hline Age Range & Head & $\begin{array}{c}\text { Married } \\
\text { Spouse }\end{array}$ & $\begin{array}{c}\text { Cohabiting } \\
\text { Spouse }\end{array}$ & Child & Other & Total \\
\hline United Kingdom & & & & & & \\
20-29 & 37.3 & 17.6 & 11.2 & 25.0 & 9.0 & 100.0 \\
$30-39$ & 55.7 & 33.7 & 5.5 & 4.0 & 1.1 & 100.0 \\
40-49 & 58.9 & 35.9 & 2.7 & 2.0 & 0.7 & 100.0 \\
$50-59$ & 62.6 & 33.8 & 1.7 & 1.0 & 1.0 & 100.0 \\
60-69 & 66.0 & 31.4 & 0.6 & 0.3 & 1.6 & 100.0 \\
$70+$ & 80.6 & 25.8 & 0.4 & 0.0 & 3.2 & 100.0 \\
All & 58.1 & 28.1 & 4.3 & 6.5 & 3.0 & 100.0 \\
United States & & & & & & \\
20-29 & 47.0 & 21.2 & 5.0 & 24.3 & 2.5 & 100.0 \\
30-39 & 59.0 & 33.1 & 3.0 & 4.0 & 1.0 & 100.0 \\
$40-49$ & 59.2 & 35.6 & 1.8 & 2.2 & 1.1 & 100.0 \\
$50-59$ & 59.7 & 36.9 & 1.0 & 1.2 & 1.4 & 100.0 \\
$60-69$ & 62.7 & 33.6 & 0.5 & 0.7 & 2.6 & 100.0 \\
$70+$ & 73.4 & 18.6 & 0.2 & 0.3 & 7.5 & 100.0 \\
All & 58.7 & 30.0 & 2.3 & 6.7 & 2.4 & 100.0 \\
\hline
\end{tabular}

Note: Sample comprised of adults over age seventy; all years pooled.

two individuals in a married household are summed and treated as one. ${ }^{22}$ When there are many young married households, average assets are inflated and the age gradient of wealth is affected. ${ }^{23}$

The magnitude of the impacts of these biases on age profiles for wealth will depend to some extent on the amounts of wealth held by each group identified in table 5.19. The discussion above makes it clear that there is some reason to believe that even if there were no underlying differences in wealth between young heads and other young adults, we would still observe an unduly flat age profile. In fact, the situation is exacerbated because young heads (particularly when coupled with their spouses) typically have more assets than their peers. Taking data at the individual level once more from the BHPS, the rate of stock ownership among young (twenty-twentynine) heads and spouses is 14.7 percent, compared with 8.6 percent for young adults living in the parental home. Correspondingly, asset stocks are around 33 percent higher for this group also ("upper" estimates are $\$ 4,034$

22. Individuals in married households may also individually accumulate more wealth due to marriage selection effects (being more prudent) or if marriage encourages savings.

23. A further issue is that the way in which the BHPS data is collected; with asset stocks asked individually and then questions about joint ownership following, one might expect this to impact on the difference between our "upper" and "lower" bounds for the youngest age group, in particular. We use the upper bounds in table 5.15 . 
Table 5.20

The Effect of Household Composition on Stock and Home Equity Age Gradients: Median Values of Stocks (Stockholders), by Age (in thousands of US\$)

\begin{tabular}{lcccc}
\hline & \multicolumn{3}{c}{ United Kingdom } \\
\cline { 2 - 4 } Age Range & Households & Tax Units & Individuals & United States \\
\hline $20-29$ & 4.7 & 3.1 & 1.6 & 3.6 \\
$30-39$ & 6.2 & 4.7 & 3.0 & 10.2 \\
$40-49$ & 9.3 & 9.0 & 4.7 & 21.5 \\
$50-59$ & 15.5 & 15.6 & 7.8 & 35.8 \\
$60-69$ & 30.0 & 32.6 & 17.1 & 61.3 \\
$70+$ & 12.4 & 15.6 & 8.1 & 51.1 \\
\hline
\end{tabular}

for heads, $\$ 3,120$ for children of heads, and $\$ 612$ for non-relatives; "lower" estimates are $\$ 2,496, \$ 1,160$ and $\$ 545$, respectively).

Using the U.K. data, in which asset values are actually collected from individual household members, we can begin to understand the importance of such biases on our age-wealth profiles. ${ }^{24}$ In table 5.20 we recomputed age profiles for stock in the United Kingdom on a tax unit and an individual basis, as opposed to a household basis. For the tax unit we define as separate units all adults except spouses as opposed to just looking at all households. Spouses' assets are added to those of the heads, and the combined unit is counted only once. For the individual analysis, we divide the assets in a married household by two and count each adult in an age band as a distinct unit.

The final two columns of table 5.20 repeat the household-level medians from tables 5.10 and 5.11. The differences in age profiles across different types of units are not trivial. In particular, stock wealth is differentially lower for the youngest tax units so that the resulting tax unit and individual age gradients are much steeper than household unit gradients. For example, at a household unit in the United Kingdom the ratio of median stock wealth of the sixty-sixty-nine age band is 6.4 times that of the twenty-twenty-nine age band. The comparable U.K. number at the tax unit or individual unit level is about 10.6. These ratios are sufficiently different to raise serious questions about the sensitivity of tests of the lifecycle model to the widespread use of household unit analysis. However, no matter which U.K. unit of analysis is used, the stock age gradients are always much less than the household unit in the United States where the comparable ratio of these two age groups is 17. The U.S. number itself would be much higher at the tax or individual unit level. Thus, we conclude

24. Due to the data collection process in PSID, it is not possible to carry out this exercise on the U.S. data. 
that while household composition is an extremely important issue, the biases it creates do not substantively affect our conclusion that age gradients of housing equity are steeper in the United Kingdom, while age gradients of stocks are steeper in the United States.

\subsubsection{Other Potential Explanations}

This combination of differences in ownership and the gradient of stock versus housing equity between the United Kingdom and United States gives support to our proposed model. However, it may well be that there are many other explanations of the same phenomena that could perform equally well. We now turn to these. The first and most obvious potential candidate for these differences between the United Kingdom and the United States is the tax differentials, that is, the possibility that the preferential treatment of mortgage debt in the United States could drive all the observed differences in net housing wealth. It is certainly true that tax differences can explain why homeowners in the United States maintain a relatively large mortgage debt. However, such a difference in tax advantages will also make ownership more attractive over renting, thus making it difficult to explain the high demand for home ownership in the United Kingdom, relative to the United States, among young households.

A second possibility is that rental market inefficiencies alone could drive the observed differences. In this case, rental market inefficiencies could explain the lower use of the rental sector among younger households in the United Kingdom. However, such an explanation taken on its own cannot explain why, once one is an owner, there is a strong demand in the United Kingdom for one to pay down the mortgage and to save heavily in housing equity.

A third potential explanation is that the right-to-buy policy is in line with the predictions of our model because it makes home ownership more attractive for lower- to middle-income groups in the United Kingdom. These are certainly people who can be expected to want to insure against house price risk. However, they will typically not be the young. The rightto-buy is available to existing public sector renters; consequently, it was most important in getting middle-aged public sector renters to move into home ownership in the mid-1980s when the policy was enacted.

Finally, we consider the possibility that differences are driven solely by differences in the fixed costs or transactions costs associated with stock ownership. Extensive privatization and demutualization in the United Kingdom over this period created many middle-income stock owning households who typically held very small values of one or two privatized stocks. This could explain the relatively low share of wealth held in stock in the United Kingdom, but again it cannot explain the high fraction of wealth held in housing equity and why this is particularly the case among the young. 
Of course, there is always the possibility that previously discussed factors could be combining to yield the observed international differences in age gradients across the dimensions we have identified in our analysis. The full evaluation of this possibility and the corresponding inferences about the role of risk in housing decisions, in comparison to the role of tax incentives or the failure of the rental market, for example, is left as an important topic for future research in understanding U.S.-U.K. differences in household wealth portfolios.

\subsection{Conclusions}

In this paper we have attempted to address an interesting housing equity puzzle. Why do younger households in the United Kingdom accumulate so much of their wealth in housing equity rather than diversifying in stock as is true for their U.S. counterparts? In trying to address this puzzle we have built up a detailed picture of housing choices and wealth accumulation in both countries. Using available microdata sources, we have documented how this has evolved for different age groups, for different demographic groups, and for different education groups in both countries. We have shown that young adults in the United Kingdom leave their parental home later than in the United States, and when they do leave they are much more likely to become a homeowner rather than use the rental market. Once a homeowner they are much more likely to accumulate wealth in housing equity rather than in other investment instruments.

Why so? Is it just the differential tax treatment of mortgages or the different institutional structures of the housing and stock markets in the two countries? We argue that although these differences are real and can go some way to explaining the observed facts, something more is needed. The higher volatility of house prices in the United Kingdom was the clue. We derived a modeling framework that explains the higher volatility and uses this to explain the different gradients in housing equity and stock holdings across the countries. Importantly, this model separates three dimensions of housing wealth outcomes - the demand for housing services, the owner occupation decision, and the housing equity decision.

The inefficient rental market places many more U.K. households in the owner-occupier sector at an earlier age than in the United States. The higher volatility of house prices in the United Kingdom adds to this incentive because, for those expecting to move up the house-size ladder, housing equity is an efficient insurance vehicle for house price uncertainty. The only way to invest in housing equity is to become an owner. Once an owner, this insurance mechanism increases the incentive to hold a higher proportion of wealth in housing equity rather than in some other risky asset. Where house prices are less volatile, as in the United States, this incentive is much reduced. Consequently, as households age and wish to accumulate wealth, 
they will do this more through housing equity in the United Kingdom than in the United States. We predict a higher gradient in the accumulation of stock in the United States and conversely a high gradient in the accumulation of housing equity in the United Kingdom, precisely the "puzzle" we see in the data and a fact that alternative explanations have difficulty predicting.

\section{Appendix}

Table 5A.1

Comparisons of PSID and BHPS Asset Categories

PSID

BHPS

1. Other Real Estate - second home, land, rental real estate, money owed in land contract

2. Net Vehicle Equity — wheels, cars, trucks, motor home, trailers, boats

3. Net Equity in farm or business

4. Stocks - corporate, mutual funds, investments trusts, stocks in IRAs

5. Checking, savings accounts, funds in IRAs, money market funds, treasury bills, CDs

6. Other Savings - bonds, life insurance, valuables, trust or estate rights

7. Other Debts - credit card, student loans, loans from relatives, medical or legal bills

8. Net Home Equity (home value-all mortgages)

$4+5+6-7$

$1+2+3+8+$ Net Financial Assets

Unfolding brackets
1. Value of second home

2. Net value of car(s)

3. Not available

4. "Investments": stocks, shares, mutual funds and investment trusts, bonds

5. Savings in accounts at bank, building society, including TESSAs

6. Not available

7. Other loans outstanding: credit card, bank loan, hire purchase, store card, credit union, etc.

8a. Value of residence

8 b. Outstanding mortgage on all property

Net Financial Assets:

$4+5-7$

Net Worth:

$1+2+8+$ Net Financial Assets

Questionnaire Methods:

1: banded

$2,8 \mathrm{a}, 8 \mathrm{~b}$ : value requested

$4,5,7$ : value requested, then unfolding brackets

\section{References}

Banks, J. W., and R. W. Blundell. 1994. Taxation and savings incentives in the UK. In Household saving and public policy, ed. James M. Poterba, 57-80. Chicago: University of Chicago Press. 
Banks, J. W., R. W. Blundell, and A. Brugiavini. 2001. Risk pooling, precautionary saving and consumption growth. Review of Economic Studies 68 (4): 757-79.

Banks, J. W., R. W. Blundell, and J. Smith. 2000. Wealth inequality in the United States and Great Britain. Working Paper no. 2000/20. Institute for Fiscal Studies.

Bond, S., L. Chennels, and M. Devereux. 1995. Company dividends and taxes in the UK. Fiscal Studies 16 (3): 1-18.

Chiuri, M. C., and T. Jappelli. 2000. Financial markets imperfections and homeownership: An international comparison. Working Paper no. 44. CSEF, University of Salerno.

Di Salvo, P., and J. Ermisch. 1997. Analysis of the dynamics of housing tenure choice in Britain. Journal of Urban Economics 42:1-17.

Ermisch, J. 1999. Prices, parents, and young people's household formation. Journal of Urban Economics 45:47-71.

Juster, T., J. Lupton, F. Stafford, and J. P. Smith. 2001. Savings and wealth: Then and now. University of Michigan and RAND. Unpublished Manuscript, June.

Ortalo-Magne, F., and S. Rady. 1998. Housing market fluctuations in a life-cycle economy. Discussion Paper no. 296. London: Financial Markets Group, London School of Economics.

\section{Comment John B. Shoven}

This is a tremendously valuable paper with lots of interesting facts and an innovative model to explain them. The paper compares the portfolio holdings of British and American households. They find a significant number of noteworthy differences: (1) British households have greater home equity in both absolute and relative terms in their portfolios, (2) wealth is more concentrated in the United States, (3) American households hold more financial assets in their portfolios, particularly those higher up in the wealth distribution, (4) direct participation in equity markets is greater in the United States than in Britain, but British participation increased in the 1980s, (5) homeownership increased in the United Kingdom in the 1980s, particularly among the middle aged and relatively uneducated, (6) homeownership is much higher among young adults in the United Kingdom than in the United States, (7) housing prices are higher and have been much more volatile in the United Kingdom, (8) down payment requirements for homes are much lower in the United Kingdom, (9) mortgage interest is not tax deductible in the United Kingdom as it is in the United States, and (10) U.S. and U.K. equity markets performed similarly between 1979 and 1999. That is quite a list of facts, and Banks, Blundell, and Smith deserve credit for highlighting them and developing a model that can explain many of them.

The facts that the authors concentrate on are that young people in the

John B. Shoven is Charles R. Schwab Professor of Economics at Stanford University, and a research associate of the National Bureau of Economic Research. 
United Kingdom are much more likely to own a house, they accumulate housing equity more rapidly, and they are much less likely to participate in equity markets. The authors relate these facts to others, particularly the lower down payment requirements and the more volatile housing prices in the United Kingdom. In their model, young people desire to trade up in housing as they age and as their families get larger. With volatile housing prices, a way to partially insure against price changes in the larger house you desire in the future is to own a smaller house in the same market. The assumption is that house prices are much more closely correlated with other houses in the same market than they are with equity returns. In such a situation, saving for your next house by investing in equities is far riskier than saving by accumulating equity in your own home. Once you purchase a home, paying down the mortgage is advantageous in the United Kingdom because of the lack of mortgage interest deductibility. In the United States, with less volatile housing prices, with a better rental market, and with mortgage interest deductibility, the pattern of homeownership is quite different. I found the Banks, Blundell, and Smith model quite ingenious in that (1) it makes sense, and (2) it implies that riskier house prices actually stimulate the demand for owner occupation.

Banks, Blundell, and Smith have some explanations for why house prices are more volatile in the United Kingdom (e.g., lower supply elasticity due to higher population density), but they don't explain why down payment requirements on homes are lower in the United Kingdom. One would think that lending institutions would require higher down payments in more volatile markets. So, one question that they left unanswered was whether the higher downpayment requirements in the United States were the result of some form of market failure.

A bigger problem that I have with the paper is that it is difficult to put the portfolio differences between the United States and the United Kingdom into perspective when the paper only includes information on the two countries being examined. It isn't surprising that portfolio behavior is different in the United Kingdom and the United States; the more interesting question is whether these differences are unusually large. For instance, how do the observed differences compare with California versus Idaho, the United Kingdom versus Sweden, or the United States versus Canada? I am still wondering whether the United States and the United Kingdom are more similar than most countries or regions, or more different.

Another matter worthy of further study is the extent to which private portfolio differences reflect different government policies. The two countries differ in whether they offer public health insurance, in the cost of higher education, and in the public and private retirement systems. Private saving and portfolios presumably reflect the different government and institutional policies in the two countries. Are the tastes and preferences of Americans and the British similar, with their behavior differences simply 
reflecting the different institutional environments in which they live? I couldn't answer this question from reading the paper.

Despite my desire for even more analysis and information, I think that this paper adds a lot to the literature. It identifies some of the significant factors accounting for the portfolio differences between U.S. and U.K. households. In fact, it is so successful that I hope that these or other researchers will ask these same questions for additional countries and regions of the world. Then we will learn whether the United Kingdom and the United States are really that (relatively) different. 